\begin{tabular}{|l|l|l|l|}
\hline $\begin{array}{l}\text { Eiszeitalter und Gegenwart } \\
\text { Quaternary Science Journal }\end{array}$ & 57/1-2 & 179-209 & Hannover 2008 \\
\hline
\end{tabular}

\title{
Surface exposure dating with cosmogenic nuclides
}

\author{
SusAn Ivy-Ochs \& Florian Kober ${ }^{*}$
}

\begin{abstract}
In the last decades surface exposure dating using cosmogenic nuclides has emerged as a powerful tool in Quaternary geochronology and landscape evolution studies. Cosmogenic nuclides are produced in rocks and sediment due to reactions induced by cosmic rays. Landforms ranging in age from a few hundred years to tens of millions of years can be dated (depending on rock or landform weathering rates) by measuring nuclide concentrations. In this paper the history and theory of surface exposure dating are reviewed followed by an extensive outline of the fields of application of the method. Sampling strategies as well as information on individual nuclides are discussed in detail. The power of cosmogenic nuclide methods lies in the number of nuclides available (the radionuclides ${ }^{10} \mathrm{Be},{ }^{14} \mathrm{C},{ }^{26} \mathrm{Al}$, and ${ }^{36} \mathrm{Cl}$ and the stable noble gases ${ }^{3} \mathrm{He}$ and ${ }^{21} \mathrm{Ne}$ ), which allows almost every mineral and hence almost every lithology to be analyzed. As a result focus can shift to the geomorphic questions. It is important that obtained exposure ages are carefully scrutinized in the framework of detailed field studies, including local terrace or moraine stratigraphy and regional morphostratigraphic relationships; as well as in light of independent age constraints.
\end{abstract}

\section{[Oberflächenexpositionsdatierungen mittels kosmogener Nukliden]}

Kurzfassung: Im letzten Jahrzehnt hat sich die Methode der Oberflächendatierung mittels kosmogener Nuklide zu einer leistungsfähigen Methode in der Quartärchronologie und quantitativen Landschaftsanalyse entwickelt. Kosmogene Nuklide werden durch kosmische Strahlung in Fest- und Lockergestein gebildet. Die Konzentrationen der kosmogenen Nuklide kann mittels Massenspektrometrie ermittelt werden. Dies ermöglicht - je nach Verwitterungssrate - die Datierung von Landschaftselementen und Landschaftsformen mit Altern zwischen einigen 100 Jahren bis über 10 Millionen Jahren. Neben einem Abriss der historischen Entwicklung und Theorie der Oberflächendatierung mittels kosmogener Nuklide enthält dieser Artikel eine ausführliche Übersicht der zahlreichen Anwendungsgebiete dieser Methode. Probenahmestrategien und die Eigenheiten der einzelnen Nuklide werden im Detail besprochen. Die Vielzahl der mit dieser Methode in den verschiedensten Mineralien bestimmbaren Nuklide (Radionuklide ${ }^{10} \mathrm{Be},{ }^{14} \mathrm{C},{ }^{26} \mathrm{Al}$ und ${ }^{36} \mathrm{Cl}$ und Edelgase ${ }^{3} \mathrm{He}$ und ${ }^{21} \mathrm{Ne}$ ) erlaubt die Beprobung und Analyse verschiedenster Lithologien. Der erreichte hohe Entwicklungsstand der Methode erlaubt es den Fokus auf die eigentlichen geomorphologischen Fragestellungen zu legen. Die Sensitivität der kosmogenen Oberflächendatierungsmethode muss trotzdem sorgfältig im Rahmen ausführlicher Feldstudien erfolgen, wie zum Beispiel durch die Analyse von lokalen und regionalen Terrassen- oder Moränenstratigraphien oder durch den Vergleich mit anderen Datierungsmethoden.

Keywords: cosmogenic radionuclides, cosmogenic noble gases, surface exposure dating

\footnotetext{
*Addresses of authors: S. Ivy-Ochs, Institute of Particle Physics, ETH Zurich, 8093 Zurich, Switzerland and Institute of Geography, University of Zurich , 8057 Zurich, Switzerland. E-Mail: ivy@phys.ethz.ch; F. Kober, Institute of Geology, ETH Zurich, 8092 Zurich, Switzerland and Institute of Isotope Geology, ETH Zurich, 8092 Zurich, Switzerland.
} 


\section{Introduction and history}

Cosmogenic nuclides build-up predictably with time in minerals exposed to cosmic rays. Therefore measuring their concentrations allows determination of how long rocks or sediment have been exposed at or near the surface of the Earth (Lal 1991; Gosse \& Phillips 2001). At present the most commonly utilized nuclides are the radionuclides ${ }^{10} \mathrm{Be},{ }^{14} \mathrm{C},{ }^{26} \mathrm{Al}$, and ${ }^{36} \mathrm{Cl}$ and the stable noble gases ${ }^{3} \mathrm{He}$ and ${ }^{21} \mathrm{Ne}$ (Table 1 ). Because of the wide variety of nuclides available (with different half-lives or stable) and the fact that they can be measured in a variety of minerals a broad spectrum of geomorphological problems can be addressed (Fig. 1).

By measuring the concentrations of cosmogenic nuclides rock surfaces themselves can be directly dated. This is a unique and powerful tool never before available to geomorphologists.
Bedrock landforms, fluvially- or glacially-polished bedrock surfaces, fault footwall faces, and landslide bedrock detachment surfaces can be sampled and dated directly. There is no other method where this is possible. Sedimentary units such as moraines, landslide deposits, fluvial terraces, debris flows or alluvial fans can be directly dated by sampling boulder surfaces or by taking samples made up of numerous clasts. Sites unsuitable for luminescence techniques may be dated with cosmogenic nuclide methods, for example sediments that have not been exposed to light long enough or coarsegrained material. In the past geomorphology has relied on radiocarbon for the indirect dating of landforms. The upper age limit for radiocarbon dating of organic material is about 50 $\mathrm{ka}$, whereas under certain conditions landform ages on the order of tens of millions years can be measured with exposure dating (SCHÄFER et al. 1999; DunAi et al. 2005). For radiocarbon

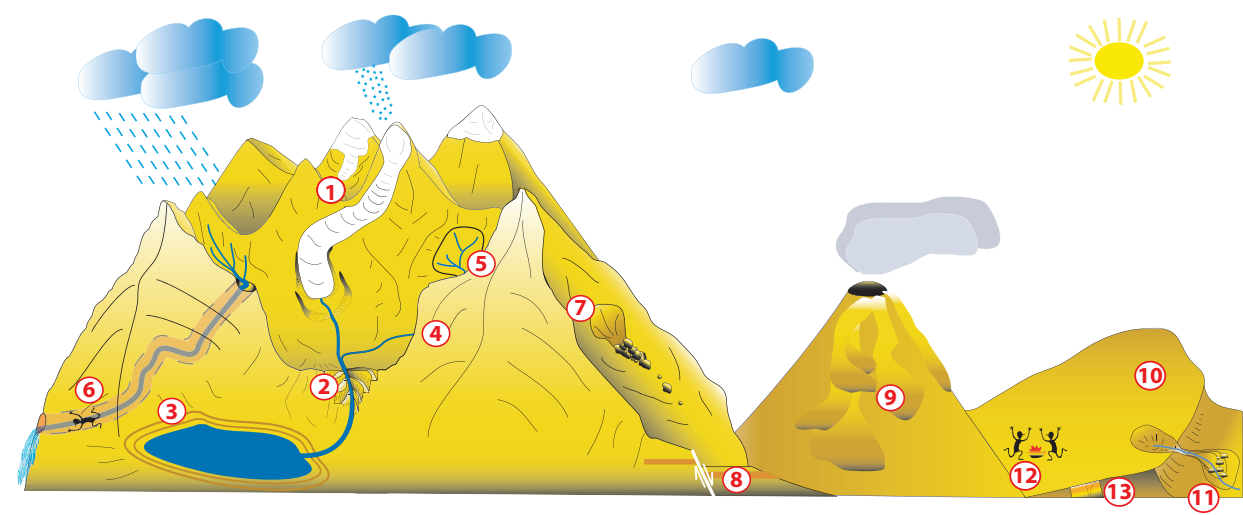
(1) glacial chronologies
(alpine, ice-sheets)
(5) catchment wide denudation rates
(2) fluvial chronologies
(6) burial chronologies
(9) volcanic eruption chronologies
(3) shoreline chronologies (terraces, lacustrine, marine)
(4) hillslope rates
(caves, terraces, paleosols) (11) alluvial fan chronologies
(7) landslide chronologies
(8) fault scarp chronologies
(12) archeology
(13) pedogenic chronologies

Fig. 1: Schematic diagram showing the various landforms that can be dated and approaches for using cosmogenic nuclides to address questions of timing and rates of landscape change (see also BIERMAN \& NICHOLS 2004).

Abb. 1: Überblick über die Landschaftsformen und Landschaftselemente die mittels kosmogener Nuklide datiert oder deren Prozessraten quantifiziert werden können (siehe auch BIERMAN \& NichOLS 2004). 
dating organic material must be present in the sediment, which is not the case in most high alpine early Holocene or Lateglacial deposits. Finally organic material included in sediments is not dating the landform itself, the relationship of the organic material to the landform can never be unequivocally established. Entrained wood fragments are simply older than the enclosing sediment.

Because of the presence of higher concentrations (production rates are higher in space than they are on earth) cosmogenic nuclides were initially investigated in lunar and meteorite samples already beginning in the 1950's (FinKel \& Suter 1993 and references therein). Earliest attempts to measure cosmogenic nuclides in terrestrial rocks were made by DAVIS \& Schaeffer (1955) and Srinivasan (1976). DAvis \& SchaEFFer (1955) used low-level decay counting to measure ${ }^{36} \mathrm{Cl}$ in a high- $\mathrm{Cl}$ phonolite from unglaciated high elevation sites in the Rocky Mountains. In 1976, Srinivasan analyzed the cosmogenic noble gas ${ }^{126} \mathrm{Xe}$ in barite from a sedimentary unit (SRINIVASAN 1976) and highlighted the potential of noble gases in surface exposure dating (NIEDERMANN 2002). Routine measurement of cosmogenic nuclides and use of cosmogenic nuclides for determi- nation of exposure histories and erosion rates only became possible after the development of accelerator mass spectrometry (AMS), and the construction of high sensitivity noble gas mass spectrometers between 1970 and 1980. These technical developments opened the way to measurements of exceedingly low nuclide concentrations. In the late 1970s first accelerator measurements were reported for ${ }^{14} \mathrm{C}$ (Bennett et al. 1977; Nelson et al. 1977), ${ }^{10} \mathrm{Be}$ (RAISBECK et al. 1978), ${ }^{26} \mathrm{Al}$ (RAISBECK et al. 1979) and ${ }^{36} \mathrm{Cl}$ (Elmore et al. 1979). Early measurements of cosmogenic nuclides in rock and sediment samples were made using ${ }^{3} \mathrm{He}$ (Kurz 1986), ${ }^{10} \mathrm{Be}$ and ${ }^{26} \mathrm{Al}$ (KLEIN et al. 1982), ${ }^{21} \mathrm{Ne}$ (Marti \& Craig 1987), ${ }^{36} \mathrm{Cl}$ (KubiK et al. 1984; Phillips et al. 1986), and ${ }^{14} \mathrm{C}$ (Jull et al. 1992). In 1991, LAL presented detailed terrestrial cosmic ray systematics, setting the standards for production rate and scaling formalisms as well as discussing potential applications and promising nuclide combinations (LAL 1991). Gosse \& Phillips (2001) published a comprehensive review of cosmogenic nuclide methods in the Earth Sciences including the appropriate equations. Further summaries are given by Nishizumi et al. (1993), Cerling \& Craig (1994a), Bierman et al. (2002), Morris

Table 1: Nuclide characteristics Mineral-Nuclide overview.

Tab. 1: Überblick über die kosmogenen Nuklide und deren Charakteristika.

\begin{tabular}{|c|c|c|c|c|c|c|c|}
\hline Nuclide & Half-life & $\begin{array}{c}\text { Other } \\
\text { isotopes }\end{array}$ & $\begin{array}{c}\text { meas. } \\
\text { method }\end{array}$ & $\begin{array}{c}\text { Target } \\
\text { elements }\end{array}$ & $\begin{array}{c}\text { Production rate } \\
\text { atoms/g.yr* }\end{array}$ & Advantages/minerals used & Disadvantages \\
\hline${ }^{10} \mathrm{Be}$ & $1.51 \mathrm{Myr}$ & ${ }^{9} \mathrm{Be}$ & AMS & $\begin{array}{l}\mathrm{O} \\
\mathrm{Si}\end{array}$ & 5 & quartz resistant and ubiquitous & $\begin{array}{l}\text { low production rate, }{ }^{10} \mathrm{~B} \text { interference in } \mathrm{AMS} \\
\text { generally restricted to quartz (no meteoric }{ }^{10} \mathrm{Be} \text { ) }\end{array}$ \\
\hline${ }^{26} \mathrm{Al}$ & $716 \mathrm{kyr}$ & ${ }^{27} \mathrm{Al}$ & AMS & $\mathrm{Si}$ & 31 & $\begin{array}{l}\text { high production rate } \\
\text { quartz resistant and ubiquitous }\end{array}$ & $\begin{array}{l}\text { restricted to quartz (low } \mathrm{Al} \text { ) } \\
\text { accurate determination of }{ }^{27} \mathrm{Al} \text { required }\end{array}$ \\
\hline${ }^{36} \mathrm{Cl}$ & $301 \mathrm{kyr}$ & ${ }^{35} \mathrm{Cl},{ }^{37} \mathrm{Cl}$ & AMS & $\begin{array}{c}\mathrm{Ca} \\
\mathrm{K} \\
{ }^{35} \mathrm{Cl}\end{array}$ & $\begin{array}{l}\text { composition dep. } \\
\text { e.g. } 10 \text { granite } \\
\text { e.g. } 20 \text { limestone }\end{array}$ & $\begin{array}{l}\text { low detection limit (low AMS Bkgd) } \\
\text { any rock type, silicates \& carbonates }\end{array}$ & $\begin{array}{l}\text { complicated production } \\
{ }^{36} \mathrm{~S} \text { interference in AMS } \\
\text { accurate determination of total } \mathrm{Cl} \text { required } \\
\text { determination of rock composition required }\end{array}$ \\
\hline${ }^{14} \mathrm{C}$ & $5.73 \mathrm{kyr}$ & ${ }^{12} \mathrm{C},{ }^{13} \mathrm{C}$ & AMS & $\mathrm{O}$ & 16 & $\begin{array}{l}\text { useful for short timescales } \\
\text { quartz resistant and ubiquitous }\end{array}$ & $\begin{array}{l}\text { short half-lfe } \\
\text { atmospheric }{ }^{14} \mathrm{C} \text { contamination }\end{array}$ \\
\hline${ }^{3} \mathrm{He}$ & stable & ${ }^{4} \mathrm{He}$ & static mass spec. & many & 120 & $\begin{array}{l}\text { high production rate } \\
\text { useful for long time scales } \\
\text { pyroxene, olivine }\end{array}$ & $\begin{array}{l}\text { diffuses out of quartz or volcanic groundmass } \\
\text { radiogenic/nucleogenic/magmatic correction } \\
\text { beware pre-exposure }\end{array}$ \\
\hline${ }^{21} \mathrm{Ne}$ & stable & ${ }^{20} \mathrm{Ne},{ }^{22} \mathrm{Ne}$ & static mass spec. & $\begin{array}{l}\mathrm{Mg} \\
\mathrm{Si}\end{array}$ & 20 & $\begin{array}{l}\text { useful for long time scales, }>50 \mathrm{ka} \\
\text { quartz, olivine, pyroxene }\end{array}$ & $\begin{array}{l}\text { nucleogenic/magmatic correction } \\
\text { high air background possible } \\
\text { beware pre-exposure }\end{array}$ \\
\hline
\end{tabular}

*production rates (Gosse \& PhilLIPs 2001) 
et al. (2002), Niedermann (2002), Cockburn \& SuMmerfield (2004). In this review we focus on surface exposure dating of landforms and deposits. The use of cosmogenic nuclides methods in Archeology is discussed in AKÇAR et al. (2008a). Burial dating is dealt with in the paper by DeHNERT \& SCHLÜCHTER (2008). For readers interested in the use of cosmogenic nuclides to determine landscape denudation rates we refer to von Blanckenburg (2005), Granger (2006; 2007) and Granger \& Riebe (2007).

\section{Production of cosmogenic nuclides}

The Earth is constantly being bombarded by cosmic rays (primarily protons, alpha particles as well as other heavier nuclei). The primary cosmic ray flux consists of galactic and solar cosmic rays with the former clearly being more important for production of cosmogenic nuclides in minerals (LAL \& Peters 1967). Interactions of high-energy cosmic ray particles with nuclei in the Earth's atmosphere result in a cascade of secondary particles (especially neutrons). This means that in traversing the atmosphere, the flux of cosmic ray particles first increases (in the first few kilometers) then steadily decreases. Consequently, nuclide production rates in rocks at the surface of the earth are lower at lower altitude. Primary galactic cosmic rays (especially the lower energy part) are modulated by the Sun's magnetic field. High solar activity reduces the primary cosmic ray flux. Cosmic ray particles are deflected by the Earth's predominantly-dipole magnetic field. The magnetic field impedes and deflects particles with lesser energies at lower latitudes. As a consequence cosmic ray intensity and therefore nuclide production is higher at the poles than at the equator. At sea level production rates are about half at the equator compared to what they are at the poles. The altitude and latitude dependence of cosmogenic nuclide production rates reflects this modulation of the cosmic ray flux by the earth's magnetic field and the atmosphere (Fig. 2) (Gosse \& Phillips 2001, MASARIK et al. 2001). Several physical models have been presented for the scaling of

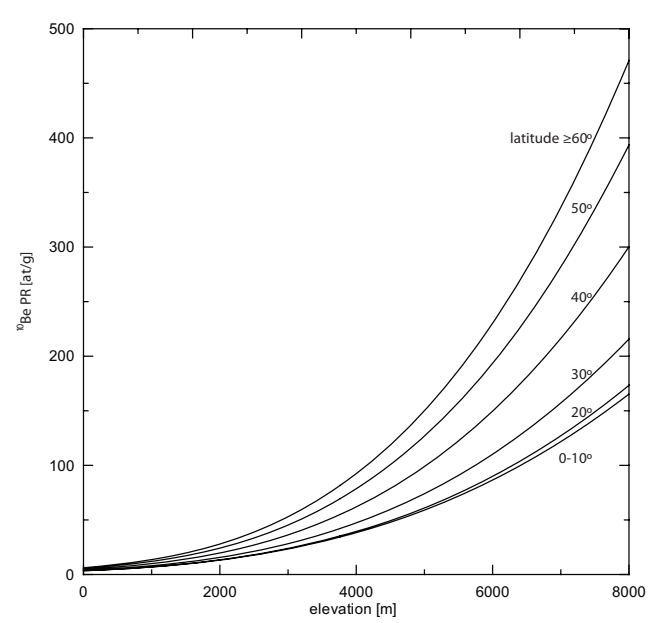

Fig. 2: Production of rate of ${ }^{10} \mathrm{Be}$ in quartz as a function of geomagnetic latitude and altitude (based on STONE 2000). The production rates have been normalized to sea level and high latitude. At low latitude, production rates are lower than at high latitude. Production rates increase exponentially with increasing altitude.

Abb. 2: Produktion von ${ }^{10} \mathrm{Be}$ in Quarz in Abhängigkeit der geomagnetischen Position und Höhe über Meeresspiegel (nach STONE 2000). Die Berechnungen sind skaliert auf Meeresspiegelhöhe und hohe geomagetische Breiten. In niederen Breiten ist die Produktionsrate kleiner als in hohen Breiten. Die Produktionsraten steigen exponentiell mit der Höhe über dem Meer an.

production rates from their sea level and high latitude values to the altitude and latitude of the sampling site (LAL 1991; DunAI 2000; 2001; Stone 2000; Desilets \& Zreda 2001; Pigati \& Lifton 2004; Muzikar 2005; Desilets et al. 2006a) (see detailed discussion in BALCO et al. 2008). Key differences between the systems include the method of modelling the variation of the neutron flux with altitude and how past changes in the magnetic field are incorporated (BALCO et al. 2008). At present most studies use the production rates and scaling system of Stone (2000) for ${ }^{10} \mathrm{Be}$ and ${ }^{26} \mathrm{Al}$. This allows a certain degree of intercomparison. Although the suitability of this protocol for samples at high altitude is under discussion (see BALCO et al. 2008). In any case it is crucial when 
calculating an exposure age to use the same scaling formalities as were used for the original production rate calculations. The University of Washington/CRONUS-Earth website (http: //hess.ess.washington.edu/math/) allows the consistent comparison of data from different sites as well as presents detailed discussion of the differences and similarities of the various scaling systems (BALCO et al. 2008). Another website where these calculations can be done is cosmocalc.googlepages.com (VERMEESCH 2007). Cosmogenic nuclides are produced within minerals by several reactions (Table 2). These include spallation, muon-induced reactions and low-energy (epithermal and thermal) neutron capture (LAL \& Peters 1967). During spallation a secondary cosmic ray neutron with sufficient energy hits the target element and one or more particles are ejected from the nucleus leaving the cosmgenic nuclide in the target element's site in the mineral lattice. Cosmogenic nuclides are also produced through interactions of muons with the target element (capture of slow muons and stopping of fast muons).

Because they are reacting with target elements in rocks the flux of secondary cosmic ray particles decreases (is attenuated) with depth into rock or sediment. Production due to spallation decreases exponentially with depth (LAL 1991) (Fig. 3). Muons are less apt to react than neutrons thus they penetrate deeper into the Earth's surface and production due to muons becomes increasingly important below depths of about 2 $\mathrm{m}$ (in a rock of density $2.7 \mathrm{~g} \mathrm{~cm}^{-3}$ ). The decrease of production depth profile for muons is described by equations with several exponentionals (Schaller et al. 2001; 2002; Granger \& SMith 2000) (see also Dehnert \& SchlÜChter 2008).

${ }^{36} \mathrm{Cl}$ differs somewhat from the other nuclides. In rocks with sufficient natural $\mathrm{Cl}\left({ }^{35} \mathrm{Cl}\right.$ and $\left.{ }^{37} \mathrm{Cl}\right){ }^{36} \mathrm{Cl}$ is produced through low-energy (thermal and epithermal) neutron capture on ${ }^{35} \mathrm{Cl}$ and to a lesser extent on ${ }^{39} \mathrm{~K}$ (Table 2); in addition to spallation and muon-related reactions. Low-energy neutrons can diffuse back out of a rock surface (FABRYKA-MARTIN 1988). As a result of this neutron leakage, production of ${ }^{36} \mathrm{Cl}$ by neutron capture peaks about $20 \mathrm{~cm}$ down into the rock (Fig. 4). The shape of this curve depends on rock composition (proportion of target elements) and density (FABRYKA-Martin 1988; LiU et al. 1994; Phillips et al. 2001). Rocks with little natural $\mathrm{Cl}$ will have negligable low-energy neutron capture

Table 2: Main reactions to produce cosmogenic nuclides on the Earth.

Tab. 2: Hauptreaktionen kosmogener Nuklide an der Erdoberfläche.

\begin{tabular}{cccc}
\hline Target element & Spallation & Negative-muon capture & $\begin{array}{c}\text { Low-energy neutron } \\
\text { capture }\end{array}$ \\
\hline $\mathrm{O}$ & ${ }^{16} \mathrm{O}(\mathrm{n}, 2 \mathrm{pn}){ }^{14} \mathrm{C}$ & ${ }^{16} \mathrm{O}\left(\mu^{-}, \mathrm{pn}\right){ }^{14} \mathrm{C}$ & \\
& ${ }^{16} \mathrm{O}(\mathrm{n}, 4 \mathrm{p} 3 \mathrm{n}){ }^{10} \mathrm{Be}$ & ${ }^{16} \mathrm{O}\left(\mu^{-}, 3 \mathrm{p} 3 \mathrm{n}\right){ }^{10} \mathrm{Be}$ & \\
$\mathrm{Si}$ & ${ }^{28} \mathrm{Si}(\mathrm{n}, \mathrm{p} 2 \mathrm{n}){ }^{26} \mathrm{Al}$ & ${ }^{28} \mathrm{Si}\left(\mu^{-}, 2 \mathrm{n}\right){ }^{26} \mathrm{Al}$ & \\
& & & \\
$\mathrm{Na}$ & ${ }^{28} \mathrm{Si}(\mathrm{n}, 2 \alpha)^{21} \mathrm{Ne}$ & & \\
$\mathrm{Mg}$ & $\mathrm{Na}(\mathrm{n}, \mathrm{p} 2 \mathrm{n}){ }^{21} \mathrm{Ne}$ & & \\
$\mathrm{Al}$ & ${ }^{24} \mathrm{Mg}(\mathrm{n}, \alpha){ }^{21} \mathrm{Ne}$ & ${ }^{39} \mathrm{~K}(\mathrm{n}, \alpha){ }^{36} \mathrm{Cl}$ \\
$\mathrm{K}$ & ${ }^{27} \mathrm{Al}(\mathrm{n}, 3 \mathrm{p} 4 \mathrm{n}){ }^{21} \mathrm{Ne}$ & & \\
$\mathrm{Ca}$ & ${ }^{39} \mathrm{~K}(\mathrm{n}, 2 \mathrm{p} 2 \mathrm{n}){ }^{36} \mathrm{Cl}$ & ${ }^{39} \mathrm{~K}\left(\mu^{-}, \mathrm{p} 2 \mathrm{n}\right){ }^{36} \mathrm{Cl}$ & \\
$\mathrm{Cl}$ & ${ }^{40} \mathrm{Ca}(\mathrm{n}, 3 \mathrm{p} 2 \mathrm{n}){ }^{36} \mathrm{Cl}(\mathrm{n}, \gamma){ }^{36} \mathrm{Cl}$ \\
\hline
\end{tabular}




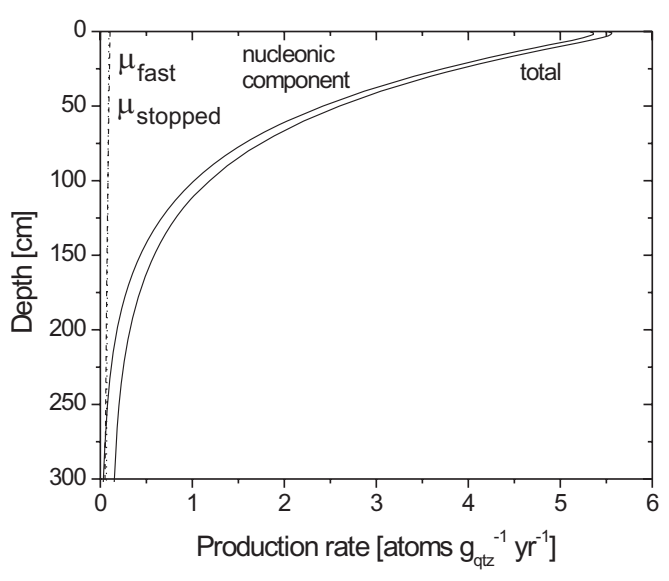

Fig. 3. Production rate of ${ }^{10} \mathrm{Be}$ in quartz as a function of depth at sea level and high latitude. The total production is a composite of the production by neutron spallation, stopped muons, and fast muons.

Abb. 3: Produktion von ${ }^{10} \mathrm{Be}$ in Quarz in Abhängigkeit der Tiefe, skaliert auf Meeresspiegelhöhe und hohe geomagnetische Breiten. Die Gesamtproduktion ist die Summe aus Spallations-, gestoppten und schnellen Muonenreaktionen.

production and the production depth profile will be spallation-dominated and resemble the curve for ${ }^{10} \mathrm{Be}$ (Fig. 3). Complete equations for calculating depth profiles are given in Gosse \& Phillips (2001).

Shielding by surrounding hillslopes and mountains reduces the cosmic ray flux to the sampling site leading to lower production. Similarly dipping of the rock surface decreases the production rate. Shielding corrections are done following Dunne et al. (1999) (see also Gosse $\&$ Phillips 2001). Calculation of these correction factors is also possible through the internet (http://hess.ess.washington.edu/math/).

Cosmogenic nuclides [atoms $\mathrm{g}^{-1}$ ] build-up in an exposed rock surface according to the following equation:

$$
\mathrm{C}_{(\mathrm{t})}=\frac{\mathrm{P}_{(0)}}{\lambda+\frac{\rho \varepsilon}{\Lambda}}\left(1-\mathrm{e}^{-\left(\lambda+\frac{\rho \varepsilon}{\Lambda}\right) \mathrm{t}}\right)+\mathrm{C}_{\mathrm{in}} \mathrm{e}^{-\lambda \mathrm{t}}
$$

Eq. 1 where $\mathrm{P}_{(0)}$ [atoms g-1 $\mathrm{a}^{-1}$ ] is the production rate at the sampling site, $\mathrm{t}[\mathrm{a}]$ is the exposure age of the surface, $\lambda\left[\mathrm{a}^{-1}\right]$ is the decay constant, $\rho\left[\mathrm{g} \mathrm{cm}^{-3}\right]$ is the density of the irradiated material, $\varepsilon\left[\mathrm{cm} \mathrm{a}^{-1}\right]$ is the erosion rate, and $\Lambda\left[\mathrm{g} \mathrm{cm}^{-2}\right]$ is the attenuation length. $\mathrm{C}_{\text {in }}$ [atoms $\mathrm{g}^{-1}$ ] is the nuclide concentration already present at the beginning of exposure and is called inheritance. The presence of inherited nuclide concentrations will yield ages older than the true age (see also below).

Radionuclides build-up in exposed minerals until secular equilibrium is reached (saturation) which happens after about three to four halflives. At secular equilibrium the number of nuclides produced per unit time is equivalent to the number that decays; the concentration is at steady state. This is seen in Figure 5 where the the upper concentration growth curve flattens out. When the rock surface is eroding (weathering), both erosion and decay lead to loss of the nuclide. Saturation is reached earlier (after a shorter exposure period) (Fig. 6).

In the first instance, exposure ages are calculated assuming zero inheritance and without erosion such that Eq. 1 simplifies to:

$$
\mathrm{C}_{(\mathrm{t})}=\frac{\mathrm{P}_{(0)}}{\lambda}\left(1-\mathrm{e}^{-\lambda \mathrm{t}}\right)
$$

Eq. 2

Eq. 2 is solved for t. The production rate is scaled for site latitude (and when past magnetic field changes are considered longitude), altitude (Fig. 2), as well as, sample thickness, and topographic shielding. The attenuation length is $157 \mathrm{~g} \mathrm{~cm}^{-2}$ and the denstiy of crystalline rock is $2.7 \mathrm{~g} \mathrm{~cm}^{-3}$ (Gosse \& PHILlips 2001). As shown in Figure 7 the measured nuclide concentration is a direct measure of the length of the exposure period.

Where field evidence indicates that rock surface weathering (erosion) has been significant, an age is calculated by using an assumed or measured erosion rate with the following equation (Eq. 1 without the inheritance term):

$$
\mathrm{C}_{(\mathrm{t})}=\frac{\mathrm{P}_{(0)}}{\lambda+\frac{\rho \varepsilon}{\Lambda}}\left(1-\mathrm{e}^{-\left(\lambda+\frac{\rho \varepsilon}{\Lambda}\right) \mathrm{t}}\right)
$$




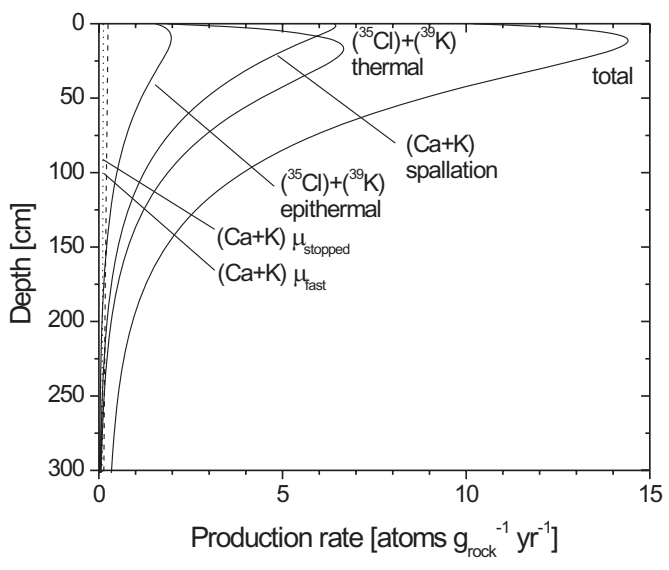

Fig. 4. Production rate of ${ }^{36} \mathrm{Cl}$ in granite with 200 ppm of $\mathrm{Cl}$ as a function of depth. The production rates are for sea level and high latitude. The total production is a composite of production by neutron spallation, thermal and epithermal neutrons, stopped and fast muons. The maximum production by thermal neutrons is highest at about $20 \mathrm{~cm}$ depth in a rock with a given density of $2.7 \mathrm{~g} \mathrm{~cm}^{-3}$. Diffusion of thermal neutrons back out of the rock in the uppermost few centimeters causes this reduction in production rate. Variation of production rates with depth calculated after Liu et al. (1994), STONE et al. (1996, 1998), and PhilLips et al. (2001).

Abb. 4: Produktion von ${ }^{36} \mathrm{Cl}$ in einem Granit (200 ppm Cl) in Abhängigkeit der Tiefe, skaliert auf Meeresspiegelhöhe und hohe geomagetische Breiten. Die Gesamtproduktion ist die Summe aus Neutronenpallations-, thermischen und epithermischen, sowohl als auch gestoppten und schnellen Muonenreaktionen. Das Maximum der Produktion durch thermische und epithermische Neutronenreaktionen wird in einer Tiefe von $20 \mathrm{~cm}$ erreicht (bei einer Dichte von $2.7 \mathrm{~g} \mathrm{~cm}^{-}$ $\left.{ }^{3}\right)$. Die Diffusion thermischer Neutronen in den oberen Zentimetern des Profils verringert die Gesamtproduktion (berechnet nach LiU et al. (1994), Stone et al. (1996, 1998), and Phillips et al. (2001)).

Crystalline rock surface erosion rates are typically less than $10 \mathrm{~mm} \mathrm{ka}^{-1}$ (COCKBURN \& Summerfield 2004). For spallation-dominated nuclides rock surface erosion has the effect of lowering the concentrations so that the measured age is younger than the true period of exposure. For ${ }^{36} \mathrm{Cl}$ exposure dating this is not always the case depending on the relative contribution of production due to low-energy neutron capture and the size of the hump in the depth profile (Fig. 4).

The upper and lower age limits for each nuclide are set by a combination of geological and methodological factors. The lower age limit for ${ }^{10} \mathrm{Be},{ }^{26} \mathrm{Al}$ and ${ }^{36} \mathrm{Cl}$ is limited predominantly by measurement capabilities. A certain amount of carrier must be added and a certain ratio of radionuclide to stable nuclide must be attained to be above the background levels. Under appropriate conditions exposure ages in the range of several hundred years can be determined (DAvis et al. 1999). Upper age limits are constrained by the nuclide half-life and the weathering rate of the rock surface (Fig. 6). In areas where rock weathering is slow exposure ages up to several million years can be determined with ${ }^{10} \mathrm{Be}$ or ${ }^{26} \mathrm{Al}$; to tens of millions with ${ }^{21} \mathrm{Ne}$. On the other hand, when a granitic rock surface is weathering at a rate of $5 \mathrm{~mm} \mathrm{ka}^{-1}$ no ages older than several hundred thousand years can be calculated. But the calculated ages may be minimum ages for that landform. Although the noble gases are stable, they too are affected by erosion and will reach pseudo-saturation just like the radionuclides (Fig. 6).

Often additional information can be gleaned about the history of a rock surface by measuring more than one nuclide (LAL 1991; Nishizumi et al. 1993; Bierman et al. 1999; Gosse \& Phillips 2001). As Eq. 3 contains two unknowns, the age and the erosion rate, using two nuclides can in some settings allow for the determination of both. One way to view two nuclide data (typically $\mathrm{Al} / \mathrm{Be}, \mathrm{Ne} / \mathrm{Be}$ ) is with the erosion island (or banana) plot (KLEIN et al. 1986; LAL 1991) (Fig. 8, 9). An important use of the erosion island plot is to readily distinguish data points that represent surfaces that have undergone continuous simple or single stage exposure (plot on or near the erosion island) versus those that reflect complex exposure involving burial (plot below the $\mathrm{Al} / \mathrm{Be}$ erosion island, above the $\mathrm{Ne} / \mathrm{Be}$ erosion 


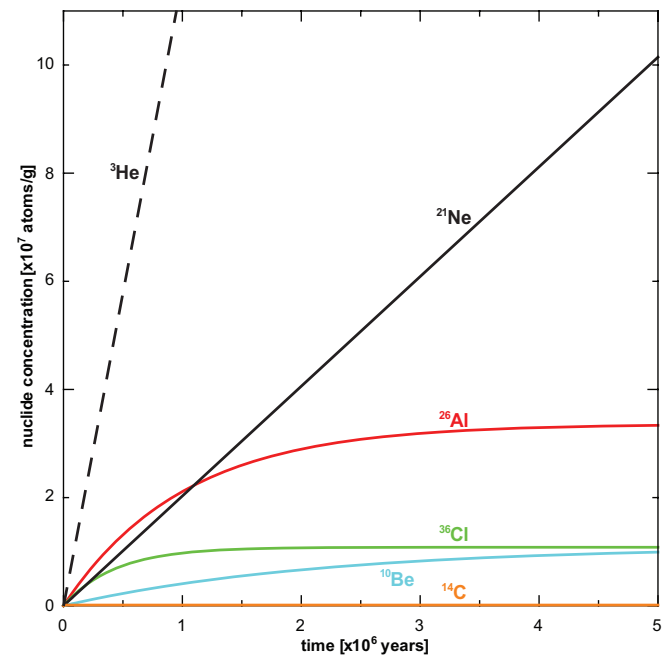

Fig. 5: Increase in concentration of the radionuclides ${ }^{10} \mathrm{Be},{ }^{26} \mathrm{Al},{ }^{36} \mathrm{Cl}$ and the stable nuclides ${ }^{3} \mathrm{He}$ and ${ }^{21} \mathrm{Ne}$ with time. Secular equilibrium, where production of radionuclides equals radioactive decay, is approached after 3-4 half-lives. The secular equilibrium concentraton sets the limit of the maximum exposure age that can be determined with a given radionuclide.

Abb. 5: Anstieg der Konzentration der Radionuklide ${ }^{10} \mathrm{Be},{ }^{26} \mathrm{Al},{ }^{36} \mathrm{Cl}$ und Edelgase ${ }^{3} \mathrm{He}$ und ${ }^{21} \mathrm{Ne}$ in Abhängigkeit von der Zeit. Ein Gleichgewichtszustand, bei dem die kosmogene Radionuklidproduktion im Gleichgewicht mit dem radioaktiven Zerfall ist, wird nach 3-4 Halbwertszeiten erreicht. Die Gleichgewichtskonzentration bestimmt die maximal mögliche Altersspanne bei der Datierung mit Radionukliden.

island, respectively; Fig. 8, 9) (see DeHnERT \& SCHLÜCHTER 2008). Spalling of slabs of rock of tens of centimenters thick may lead to data that plots inside the banana or in the complex field below the banana (BIERMAN et al. 1999; Kober et al. 2007). The minimum exposure time represented by data plotting below the erosion island is made up of continuous exposure along the outer line (bold black line) followed by burial with complete shielding (zero production). But an infinite number of periods of exposure and burial are possible which require more time (cf. BIERMAn et al. 1999). Indeed data points for rocks or sediment that were exposed then buried can arrive back inside the erosion island after a long enough period of (re)exposure. The erosion island plot can be used to estimate both exposure age and erosion rate, especially at sites where erosion rates are very low and where rocks have been exposed longer than $100 \mathrm{ka}$, for example in desert environments. For slowly eroding arid and hyperarid environments the use of ${ }^{21} \mathrm{Ne}$ (stable) measured in quartz in concert with ${ }^{10} \mathrm{Be}$ provides increased sensitivity for older, more slowly eroding surfaces (Fig. 9).

The basic assumptions that are implicit in the use of in situ-produced cosmogenic nuclides to address problems of landscape evolution are:

- the half-life of the radionuclide is known,

- production pathways and production rates including their variation in space (including with depth into the rock or sediment) are known,

- the initial nuclide concentration (inheritance) is zero or can be determined or estimated,

- the mineral has remained a closed system, i.e. there has been no gain or loss of the nuclide except due to production or decay (or through erosion).

\section{Specific nuclide characteristics}

\subsection{Radionuclides}

AMS (accelerator mass spectrometry) is used to determine concentrations of long-lived radionuclides ${ }^{10} \mathrm{Be},{ }^{14} \mathrm{C},{ }^{26} \mathrm{Al},{ }^{36} \mathrm{Cl}$ by measuring ratios relative to a standard material. In AMS interfering isobars or like-mass molecules are separated at the ion source (when they do not produce negative ions), through mass discrimination with magnetic or electrostatic analyzers (as in traditional mass spectrometry), during stripping and/or during detection (FInKel \& SUTER 1993).

Quartz is used in nearly all ${ }^{10} \mathrm{Be}$ studies. This is because it is a ubiquitous, resistant mineral that can be consistently cleaned of meteoric ${ }^{10} \mathrm{Be}$. Meteoric ${ }^{10} \mathrm{Be}$ is produced in the atmosphere. Its presence in the analyzed mineral separate 

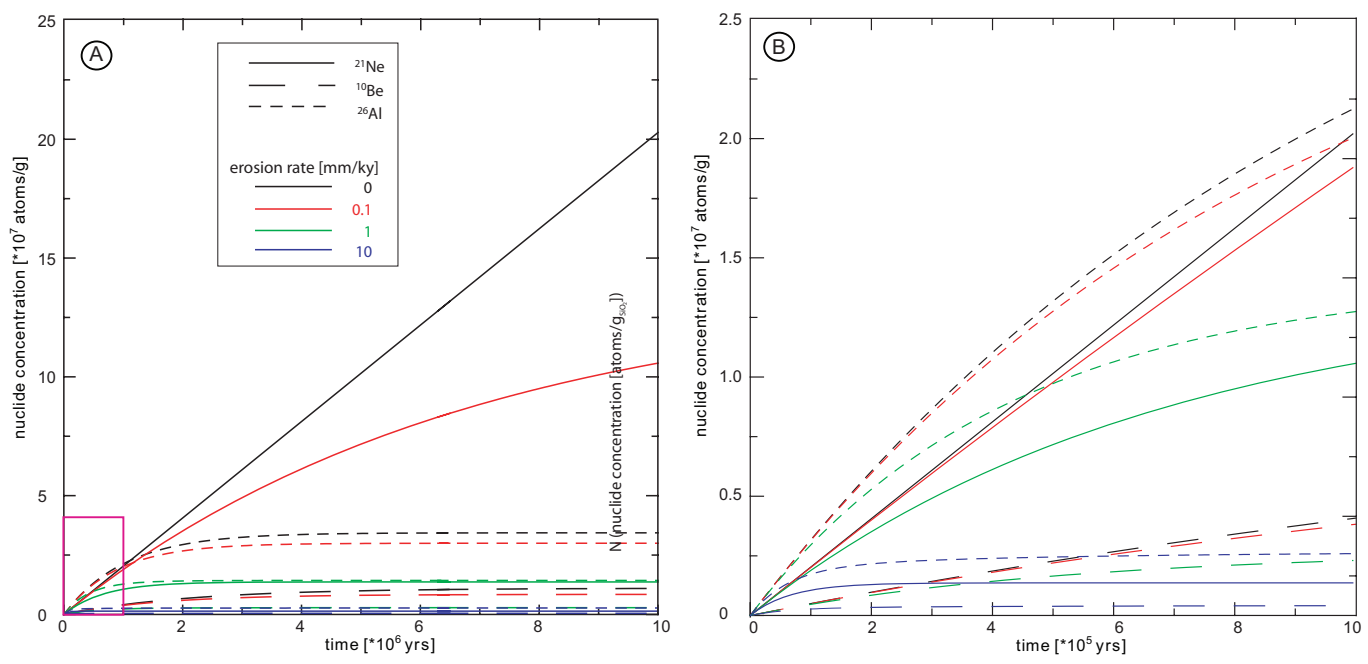

Fig. 6: Increase of the concentrations of ${ }^{10} \mathrm{Be},{ }^{26} \mathrm{Al}$, and ${ }^{21} \mathrm{Ne}$ with time taking into account different erosion rates of the exposed surface. Secular equilibrium, where radionuclide gain due to production equals loss due to radioactive decay and erosion, is approached earlier for more rapid erosion rates. A blow-up for the region 0 to $1 \mathrm{Ma}$ is shown.

Abb. 6: Anstieg der Konzentration der Radionuklide ${ }^{10} \mathrm{Be},{ }^{26} \mathrm{Al}$ und ${ }^{21} \mathrm{Ne}$ in Abhängigkeit von der Zeit und variierenden Erosionsraten an der Erdoberfläche. Ein Gleichgewichtszustand, bei dem die kosmogene Radionuklidproduktion im Gleichgewicht mit radioaktivem Zerfall und der Abnahme durch Erosion ist, wird früher erreicht, je höher die Erosionsrate ist (A). (B) zeigt einen detaillierten Ausschnitt von (A) im Zeitfenster von 0 bis 1 Million Jahre.

would lead to spurious age results. Minerals other than quartz have been tried; for example olivine and pyroxene (Nishizzumi et al. 1990; BLARD et al. 2008). It is important to note that in contrast to quartz, these minerals chemically weather to clay minerals, consequently problems removing meteoric ${ }^{10} \mathrm{Be}$ have been reported (SEIDL et al. 1997; Ivy-Ochs et al. 1998a). Several groups have tried to measure ${ }^{10} \mathrm{Be}$ in carbonate rocks (BRAUCHER et al. 2005); the affinity of ${ }^{10} \mathrm{Be}$ for clay minerals poses a significant obstacle (Merchel et al. 2008). The use of ${ }^{26} \mathrm{Al}$ is restricted to minerals with low ${ }^{27} \mathrm{Al}$ content. Too much ${ }^{27} \mathrm{Al}$ would yield a ${ }^{26} \mathrm{Al} /{ }^{27} \mathrm{Al}$ ratio too low to be measured with AMS. Conveniently, quartz satisfies the requirements for both ${ }^{10} \mathrm{Be}$ and ${ }^{26} \mathrm{Al}$ so that both can be extracted by dissolving a single quartz mineral separate. Pure quartz is obtained by selective chemical dissolution in a hot ultrasonic bath and/or on a shaker table (KoHL \& Nishiızumi 1992). Most other minerals dissolve faster than quartz in a dilute HF (ca. 4\%) solution. A carrier of ${ }^{9} \mathrm{Be}$ (about half a milligram in solution) is added to the pure quartz mineral separate which is then completely dissolved with concentrated $\mathrm{HF}$ and $\mathrm{HNO}_{3}$. Be and $\mathrm{Al}$ are separated and purified with ion exchange methods and selective $\mathrm{pH}$ precipitations (KoHL \& NishiIzUMI 1992; Ivy-Ochs 1996; vON BlanckenBuRg et al. 1996; Bierman et al. 2002) (see also http: //depts.washington.edu/cosmolab/chem). Although it has a higher production rate (Table 1 ), one disadvantage of ${ }^{26} \mathrm{Al}$ is that a separate accurate measurement (with its own uncertainties) is required to determine the ${ }^{27} \mathrm{Al}$ content of the quartz. Ratios of ${ }^{10} \mathrm{Be} /{ }^{9} \mathrm{Be}$ or ${ }^{26} \mathrm{Al} /{ }^{27} \mathrm{Al}$ are measured with AMS.

Because $\mathrm{Cl}$ is hydrophyllic contaminating meteoric ${ }^{36} \mathrm{Cl}$ (or ${ }^{37} \mathrm{Cl}$ or ${ }^{35} \mathrm{Cl}$ ) can be removed with rinsing procedures. Under most conditions any rock type or mineral separate can be used 


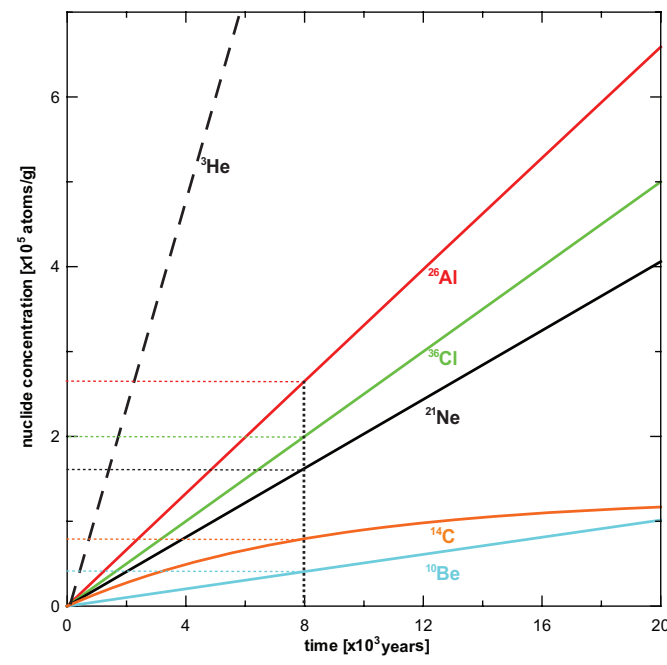

Fig. 7: Close-up of the region 0 to 20,000 years of exposure, illustrating the direct relationship between measured nuclide concentration and exposure age.

Abb. 7: Detaillierter Ausschnitt für das Zeitfenster von 0 bis 20000 Jahren, welcher die direkte Abhängigkeit des Anstiegs der Nuklidkonzentration von der Dauer der Exposition darstellt.

for ${ }^{36} \mathrm{Cl}$ exposure dating. On the other hand if secondary minerals which include meteoric ${ }^{36} \mathrm{Cl}$ precipitate (for example secondary calcite) then the system is no longer closed. Sample preparation procedures for ${ }^{36} \mathrm{Cl}$ are given in ZREDA (1994), IVY-OchS (1996), StOne et al. (1996, 1998), Ivy-Ochs et al. (2004) and Desilets et al. (2006b) (see also http://depts.washington.edu/cosmolab/chem/). Crushed rock samples are first leached several times to release any non-in situ produced $\mathrm{Cl}$. Several milligrams of carrier (in solution) of known isotopic composition (pure ${ }^{35} \mathrm{Cl},{ }^{37} \mathrm{Cl}$, or a mixture of both) are added. Carbonate rocks are dissolved with $\mathrm{HNO}_{3}$ and silicate rocks with HF. Sulfur is removed by precipitation of $\mathrm{BaSO}_{4}\left({ }^{36} \mathrm{~S}\right.$ interferes with AMS measurement of ${ }^{36} \mathrm{Cl}$ ). A crucial improvement in ${ }^{36} \mathrm{Cl}$ methodology is the implementation of isotope dilution. By adding a spike of known isotopic composition but different from the natural ratio of about $3: 1\left({ }^{35} \mathrm{Cl}:{ }^{37} \mathrm{Cl}\right)$, both the total rock $\mathrm{Cl}$ concentration and ${ }^{36} \mathrm{Cl}$ can be determined in a single target using an AMS set-up, through the measurement of ${ }^{37} \mathrm{Cl} /{ }^{35} \mathrm{Cl}$ as well as ${ }^{36} \mathrm{Cl} / \mathrm{Cl}$ (Elmore et al. 1997; Ivy-Ochs et al. 2004). This has led to marked improvements in both precision and accuracy in ${ }^{36} \mathrm{Cl}$ results (DEsILETS et al. 2006b). Because ${ }^{36} \mathrm{Cl}$ is produced from spallation of $\mathrm{Ca}$ and $\mathrm{K}$ and low-energy neutron capture on ${ }^{35} \mathrm{Cl}$ and ${ }^{39} \mathrm{~K}$ and because each rock has a different chemistry, production rates for ${ }^{36} \mathrm{Cl}$ must be calculated individually. In addition to determination of major element oxides, concentrations of B, Gd, and Sm must be determined. These elements are strong neutron absorbers and influence the proportion of low-energy neutrons that are available for neutron capture reactions on ${ }^{35} \mathrm{Cl}$ and ${ }^{39} \mathrm{~K}$. $\mathrm{U}$ and $\mathrm{Th}$ concentrations are needed to correct for background (subsurface non-cosmogenic) neutron-capture ${ }^{36} \mathrm{Cl}$ production (FABRYKA-MARTIN 1988).

${ }^{14} \mathrm{C}$ is produced in quartz by spallation of ${ }^{16} \mathrm{O}$ (Jull et al. 1992; LifTON et al. 2001; YoKOYAMA et al. 2004). Atmospheric ${ }^{14} \mathrm{C}$ contamination is removed from the surfaces and crevices of the quartz grains with acid etching (similar to that used for ${ }^{10} \mathrm{Be}$ studies; KoHL \& Nishizumi 1992) and preheating. About five grams of quartz are flux melted in a flow of oxygen (LIFTON et al. 2001) to produce $\mathrm{CO}_{2}$. which is converted to graphite using standard procedures. Carbon ratios are measured with AMS. The possibility to use a gas ion source for direct analysis of the $\mathrm{CO}_{2}$ with AMS is an exciting development. Because of difficulties in sample preparation and extraction, ${ }^{14} \mathrm{C}$ is currently used infrequently but has great potential.

\subsection{Noble gases}

For noble gas studies, mineral separates (tens to hundreds of milligrams) are pre-concentrated using heavy liquids and/or magnetic separation. Quartz is separated using the method of KoHL \& Nishizzumi (1992). Because of the small amounts necessary mineral separates can also be hand-picked under a binocular microscope. Noble gases are extracted and measured with high sensitivity static noble gas mass spectrometry (Niedermann 2002). Mineral separates 
Fig. 8: Plot of ${ }^{26} \mathrm{Al} /{ }^{10} \mathrm{Be}$ ratios versus ${ }^{10} \mathrm{Be}$ concentration showing the evolution of the ${ }^{26} \mathrm{Al} /{ }^{10} \mathrm{Be}$ ratios with time. Continuously exposed, non-eroding surfaces evolve along the bold black line. Continuously exposed surfaces eroding with steady-state erosion follow the trajectories (blue lines) that splay downward from the no-erosion line. The red line joins points of final ${ }^{26} \mathrm{Al} /{ }^{10} \mathrm{Be}$ ratios with the given erosion rates but is not an evolution line. The prescribed area is called the «steady-state erosion island». Samples that plot below the steady-state erosion island experienced a more complex exposure that involves periods of burial (see DEHNERT \& SCHLÜCHTER 2008). Samples may also plot below the erosion island if thick slabs have spalled off.

Abb. 8: Darstellung des Verhältnisses von ${ }^{10} \mathrm{Be} /{ }^{26} \mathrm{Al}$ zur ${ }^{10} \mathrm{Be}-$ Konzentration, welches die Entwicklung

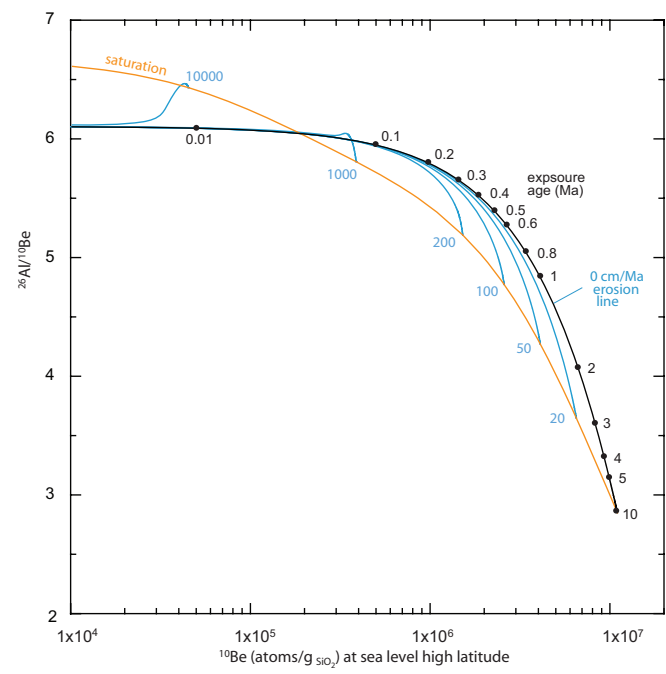
des Verhältnisses von ${ }^{10} \mathrm{Be} /{ }^{26} \mathrm{Al}$ mit der Zeit aufzeigt (als Funktion der Konzentration). Im Falle einer kontinuierlichen Exposition und Null-Erosion würde eine Probe auf der schwarzen, dicken Linie liegen. Kontinuierliche Exposition mit einer konstanten Erosionsrate würde eine Probe auf Trajektoren (blaue Linien) bewegen, die von der Null-Erosionslinie abzweigen. Die rote Linie verbindet die Endpunkte dieser Trajektoren (Gleichgewichtsendpunkt, Verhältnis von ${ }^{10} \mathrm{Be} /{ }^{26} \mathrm{Al}$ ist konstant) und ist artifiziell. Das Feld zwischen Null-Erosionslinie und der artifiziellen Linie wird als "Gleichgewichts-Erosionsinsel" bezeichnet. Probenpunkte unterhalb dieser Insel haben eine komplexe Expositionsgeschichte, einschliesslich Perioden mit Abschirmung zur kosmischen Strahlung (siehe auch Dehnert \& SchlǗchter 2008). Probenpunkte unterhalb der "Gleichgewichts-Erosionsinsel" können auch durch eine schalige Abspaltung vom Festgestein verursacht werden.

are heated to various temperature steps until the final fusion of the sample. Step-wise heating or crushing in vacuo are performed to discriminate non-cosmogenic components (nucleogenic, radiogenic, or trapped). Gas purification (separation from e.g., $\mathrm{CO}_{2}$, water vapour, and heavy noble gases) is accomplished by a combination of cryogenic traps and hot getters.

${ }^{3} \mathrm{He}$ is produced by spallation reactions of nearly all elements. ${ }^{3} \mathrm{He}$ is not measured in quartz as it diffuses out (Trull et al. 1991; BROOK \& KURZ 1993). Olivine and pyroxene phenocrysts and microphenocrysts are retentive for ${ }^{3} \mathrm{He}$ (Kurz et al. 1990; Cerling \& Craig 1994b; LiCCIARDi 1999; Fenton et al. 2001; MARCHETTI et al. 2005). The presence of radiogenic ${ }^{3} \mathrm{He}$ may limit studies to rocks with young crystallization ages (cf. NiEDERMANN 2002; WiLLIAMS et al. 2005).

${ }^{21} \mathrm{Ne}$ is produced by spallation of $\mathrm{Si}, \mathrm{Al}, \mathrm{Mg}$ and $\mathrm{Na}$ (Table 1) in quartz, olivine, pyroxene and sanidine. An important advantage of ${ }^{21} \mathrm{Ne}$ is that in contrast to ${ }^{3} \mathrm{He}$ it can be measured in quartz (GraF et al. 1991; Staudacher \& Allégre 1991). Thus three cosmogenic nuclides, ${ }^{10} \mathrm{Be}$, ${ }^{26} \mathrm{Al}$ and ${ }^{21} \mathrm{Ne}$ can be determined on aliquots of a single quartz mineral separate (Hetzel et al. 2002a,b; Kober et al. 2007). As ${ }^{14} \mathrm{C}$ is measured in quartz the potential to measure four nuclides in quartz exists. ${ }^{21} \mathrm{Ne}$ is also measured in pyroxene and olivine (Marti \& Craig 1987; StauDacher \& Allegre 1991; Poreda \& Cerling, 1992; BrUno et al. 1997; SCHÄFER et al. 1999). Kober et al. (2005) showed that the volcanic potassium feldspar sanidine retains ${ }^{21} \mathrm{Ne}$. By using sanidine one can measure ${ }^{10} \mathrm{Be},{ }^{36} \mathrm{Cl}$ and ${ }^{21} \mathrm{Ne}$ in aliquots of the same mineral separate (Ivy-Ochs et al. 2007b). Interferences due to trapped and/or nucleogenic (both non-cosmogenic) neon isotopes (Hetzel et al. 2002a) can in most cases be deconvoluted using stepwise heating of mineral separates and plotting data on the three isotope $\left({ }^{20} \mathrm{Ne},{ }^{21} \mathrm{Ne},{ }^{22} \mathrm{Ne}\right)$ plot (Graf et al. 1991; Niedermann 2002). 


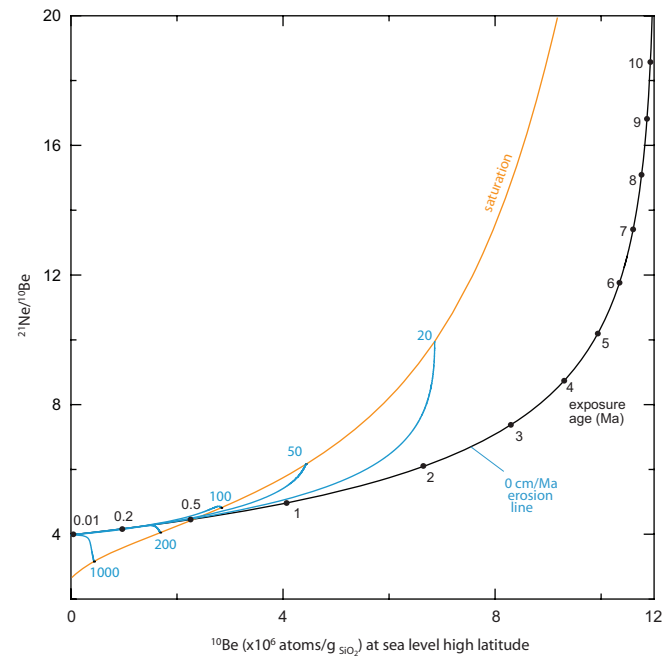

Fig. 9: Plot of ${ }^{21} \mathrm{Ne} /{ }^{10} \mathrm{Be}$ ratios versus ${ }^{10} \mathrm{Be}$ concentration showing the evolution of the ${ }^{21} \mathrm{Ne} /{ }^{10} \mathrm{Be}$ ratios with time. Continuously exposed, non-eroding surfaces evolve along the bold black line. Continuously exposed surfaces eroding with steady-state erosion follow the trajectories (blue lines) that splay upward from the no-erosion line. The red line joins points of final ${ }^{21} \mathrm{Ne} /{ }^{10} \mathrm{Be}$ ratios with the given erosion rates but is not an evolution line. The prescribed area is called the «steady-state erosion island». Samples that plot below the steady-state erosion island experienced a more complex exposure that involves periods of burial. Samples may also plot above the erosion island if thick slabs have spalled off.

Abb. 9: Darstellung des Verhältnisses von ${ }^{21} \mathrm{Ne} /{ }^{10} \mathrm{Be}$ zur ${ }^{10} \mathrm{Be}-$ Konzentration, welches die Entwicklung des Verhältnisses von ${ }^{21} \mathrm{Ne} /{ }^{10} \mathrm{Be}$ mit der Zeit aufzeigt (s. Legende Fig. 8).

\section{Sampling considerations}

Cosmogenic nuclides can be used to address a variety of problems in the Earth Sciences (Fig. 1). Two factors are key in deciding which cosmogenic nuclide (Table 1) is best suited to the geological/geomorphological problem at hand: i) the half-life of the nuclide (or stable), and ii) the bedrock geology (mineralogy) of the study area. As described above certain nuclides can only be measured in certain minerals.

Depositional landforms such as moraines (Fig. 10), fluvial terraces or alluvial fans can be dat- ed with cosmogenic nuclides. For the exposure date to represent as close as possible the true formation or abandonment age of the landform, the sampled object (boulder, clasts or bedrock) surface must have i) undergone single-stage exposure (no pre-exposure/inheritance), ii) been continuously exposed in the same position (not shifted), iii) never been covered, and iv) undergone only minimal surface weathering or erosion (not spalled). Sampling large ( $>1.5 \mathrm{~m}$ high), broad, and flat-topped boulders located in stable positions (moraine crest; flat tread of a terrace) best satisfy these conditions. Large boulders have a smaller chance of having sunk in or shifted. To avoid edge effects (MASARIK et al. 2000; MASARIK \& Wieler 2003), flat surfaces at least 20-30 cm away from an edge are sampled. Similarly pointed knobs are avoided. Careful scrutiny of candidate boulders may help one to rule out those that have spalled or toppled. The base of boulders is inspected for flakes, although this may be difficult to judge in forested settings. Sample surfaces are evaluated for post-depositional weathering, when there are step-like surfaces the highest one is sampled. A hammer and chisel, a saw or a drill are used to take several hundred grams to $1 \mathrm{~kg}$ of the upper few centimeters of the rock surface (Fig. 10). The amount of material needed depends on location (i.e. the local production rate), estimated exposure age and mineralogy ( $\%$ of the mineral needed) of the sampled surface. Because of the possibility of the data scattering, where enough suitable boulders are present at least three to five different boulders are sampled.

In most data sets the prevalence of « too young») ages far overshadows 〈>too old» ages. This has been determined based on independent age controls for the landform (e.g. ${ }^{14} \mathrm{C}$ age for a landslide) or intercomparison of dates from a single or related landform (when inversions occur etc). Most commonly, weathering of the sampled rock surface and/or degradation of the landform leads to «too young» ages. The magnitude of this effect is related to the age, location (climate, treeline location with respect to the landform), lithology (mineralogy and texture) 
and morphology of the landform (flatness of the upper surface steepness of the margins). 〈 Too old $\iota$ ages arise when the initial nuclide concentration in the sampled rock surface was not zero
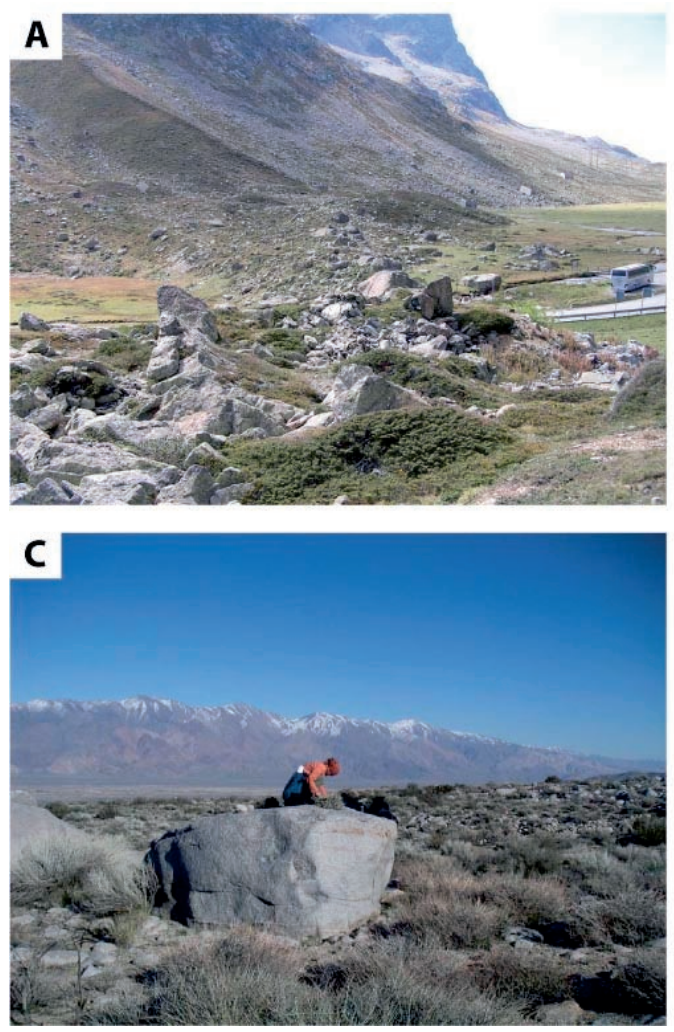

Fig. 10: Examples of exposure dated landforms:

A. View along the boulders making up the latero-terminal moraine complex at Julier Pass, left lateral moraine is seen in the upper left. Numerous boulders were dated with ${ }^{10} \mathrm{Be},{ }^{26} \mathrm{Al}$ and ${ }^{36} \mathrm{Cl}$. Exposure dates indicate moraine stabilization at $11.4 \mathrm{ka}$ (Ivy-Ochs et al. 2006),

B. Terrace levels (T2 in the center, T3 in the background) in the Pishamak area, Makran Range, SE Iran, exposure dated with both ${ }^{10} \mathrm{Be}$ and ${ }^{21} \mathrm{Ne}$ (F. KoBER, unpublished data),

C. ${ }^{10} \mathrm{Be}$ dated boulder on the Shephard Creek debris-flow fan in Owens Valley (DüHNForth et al. 2008),

D. Pahoehoe flow top from the ca. 90,000 year old ( ${ }^{3} \mathrm{He}$ ) Bar Ten flow, Arizona (Fenton et al. 2001).

Abb. 10: Beispiele von Landformen die mit kosmogenen Nukliden datiert wurden:

A: Blick entlang eines Seiten/Endmoränenkomplexes am Julier Pass, linke Seitenmoräne ist im linken oberen Bildausschnitt. Zahlreiche Blöcke wurden mit ${ }^{10} \mathrm{Be},{ }^{26} \mathrm{Al}$ und ${ }^{36} \mathrm{Cl}$ datiert. Expositionsalter geben ein Alter von 11400 Jahren an, welches als das Alter der Stabilisierung der Moränen interpretiert wird (IvYOchs et al. 2006).

B: Terrassenniveaus (T2 im Zentrum, T3 im Hintergrund des Bildes) im Gebiet um Pishamak, Makran, SEIran, datiert mit ${ }^{10} \mathrm{Be}$ und ${ }^{21} \mathrm{Ne}$ (F. KoBer et al. in Bearbeitung).

C: Blöcke eines Schuttstromes auf einem Fächer des Shephard Creeks, Owens Valley (DüHNForth et al. 2008).

D: Oberer Bereich eines Pahoehoe Lavastroms des Bar Ten Stroms, Arizona, datiert auf ca. 90000 Jahre (FEnTon et al. 2001). (inheritance). In boulders, inheritance can be acquired in bedrock exposures before the boulder falls onto the glacier or before the landslide, or when the boulder is reworked from older depo-
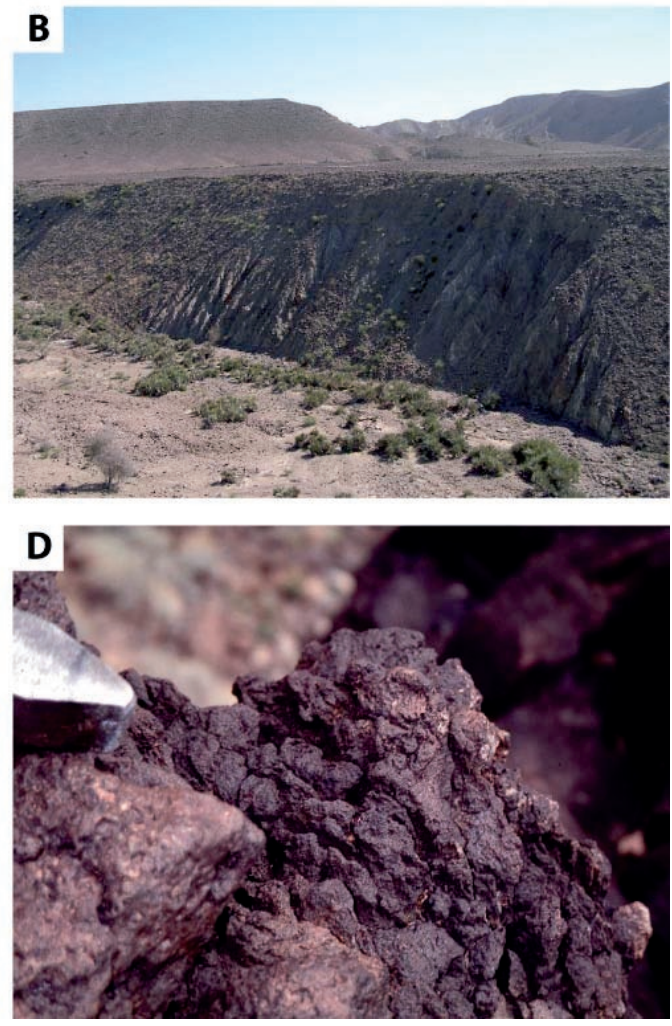


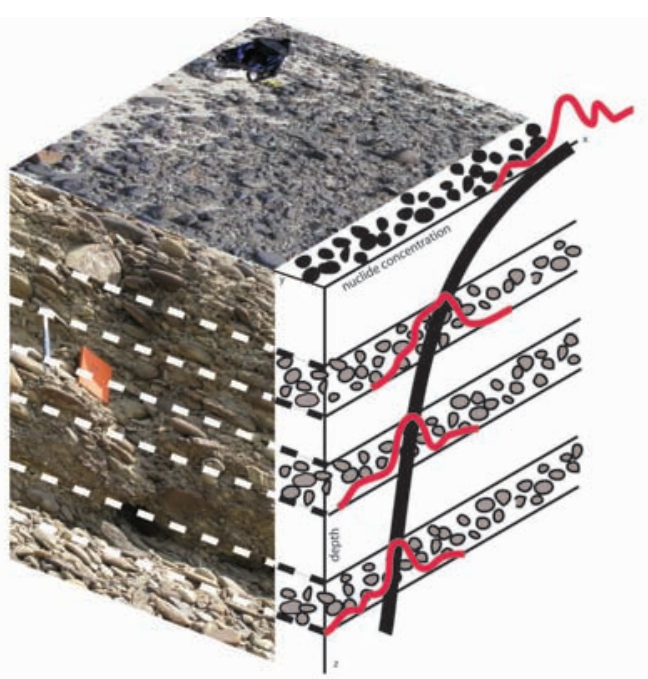

Fig. 11: Schematic sketch of a depth profile (z-axis) and cosmogenic nuclide concentrations (x-axis) in an alluvial sequence deposited in a single event. Red curves show hypothetical frequency distribution of nuclide concentrations of individual clasts, illustrating the need to amalgamate tens of clasts (ANDERSON et al. 1996; RePKA et al. 1997). Amalgamated clast samples taken in certain depth intervals show a decreasing concentration with depth.

Abb. 11: Schematische Darstellung der Nuklidkonzentration (x-Achse) mit der Tiefe (y-Achse) in einer alluvialen Ablagerungsequenz (singuläres Ereignis). Die rote Kurve zeigt die hypothetische Nuklidkonzentrationsverteilung, welche aus einer Anzahl von individuellen Kiesgeröllen gewonnen wurde. Dies zeigt, dass eine Mischung einer größeren Anzahl von Kiesgeröllen zur Datierung nötig ist (ANDERSON et al. 1996, RePKA et al. 1997). Mischproben zeigen eine Abnahme der Nuklidkonzentration mit der Tiefe.

sits. For example boulders can be pushed into new moraines without having their orientation changed (see also Ivy-OcHs et al. 2007a).

Where large boulders are not present amalgamated clast samples are analyzed (ANDERSON et al.1996; REPKA et al. 1997). This method is suitable for older landforms ( $>100 \mathrm{ka}$ ) that probably never had boulders; for example fluvial terraces. The effects of unrepresentative concentrations (too high or too low) should be smoothed out by the amalgamation of $>50$ clasts of similar size (several centimeters in diameter) (ANDERSON et al. 1996; RePKA et al. 1997). Clasts are collected from the flat part of the landform surface well away from modifying channels. In many cases the nuclide concentration due to inheritance is revealed by measuring a depth profile. Amalgamated clast samples are taken every 10-20 centimeters down to 2 meters depth (Fig. 11) (ANDERSOn et al. 1996; REPKA et al. 1997; RYERsON et al. 2006). Exposure during hill slope erosion, sediment transport, and storage in terraces may result in inheritance in clasts. Scavenging (reworking) of material from older deposits at higher elevation can also lead to inheritance in clasts (WARD et al. 2005). Where field relationships indicate that the top of the depositional surface has undergone little erosion (flat tread morphology as opposed to convex tops on terraces) or little aggradation (minimal silt layer below the top surface pavement) the shape of the depth curve reveals both age and inheritance (Fig. 12). Appropriate sediment densities must be used to calculate the model curves. Commonly the concentration in the upper several tens of centimeters is constant due to mixing (often bioturbation) (Phillips et al. 1998) (Fig. 12). Thick (more than tens of meters) rapidly deposited units may also be burial dated by measuring the concentrations of two nuclides from samples at greater depth $(>10 \mathrm{~m})$ (GRANGER \& MuZIKAR 2001; Wolkowinsky \& Granger 2004; Granger 2006) (see DeHnert \& SCHLÜChter 2008).

Several landscape evolution questions can be addressed by sampling bedrock. Bedrock samples are taken from areas that have never been covered by sediment, ice or snow. This may require sampling a steeply dipping surface and the making of the appropriate sheilding corrections (NishizUmi et al. 1989; Kelly et al. 2006). In general sampling of steep surface is avoided to circumvent the additional uncertainties associated with the dip correction.

\section{Dating of Quaternary landforms}

\subsection{Glacial landscapes}

Surface exposure dating has been used in a broad spectrum of settings in glacial landscapes. This 
includes the dating of boulders on moraines (for a recent compilation see REUTHER et al. 2006a), boulders on glacial outwash fans (PHILLIPs et al. 1997), boulders on the former margins of icedammed lakes (DAvis et al. 2006) and boulders deposited during catastrophic outburst of icedammed lakes (CERling et al. 1994; Reuther et al. 2006b). Glacially-polished bedrock is also analyzed for determining rates of ice retreat, and depth of subglacial erosion. The method of burial dating has great potential, especially in the dating of old, buried glacial deposits (see Dehnert \& Schlüchter 2008). Balco et al. (2005) used ${ }^{26} \mathrm{Al}$ and ${ }^{10} \mathrm{Be}$ ratios in quartz to determine the age of deeply buried paleosols and underlying till units.

\subsubsection{Dating of moraines}

Moraines record the location of the margins of a glacier in the past. Changes in glacier volume and length themselves reflect changes in tem-
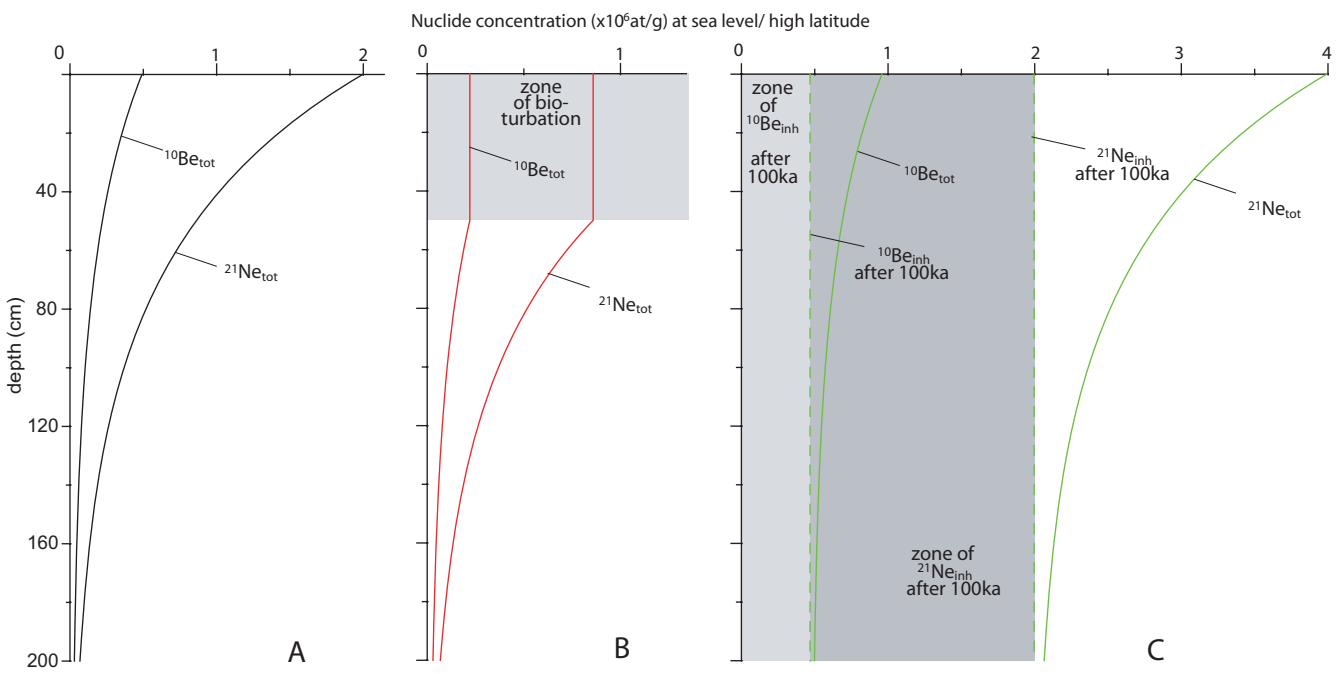

Fig. 12: ${ }^{10} \mathrm{Be}$ and ${ }^{21} \mathrm{Ne}$ concentrations with depth into a rock surface. The nuclide concentration in a sample is a composite of the inherited and the post-depositional nuclide concentration. The inherited concentration can be approximated by measuring several samples from different depths, tens of centimeters apart down to about $2 \mathrm{~m}$.

A. ${ }^{10} \mathrm{Be}$ and ${ }^{21} \mathrm{Ne}$ concentrations in a depth profile after exposure for $100 \mathrm{ka}$ with a constant erosion rate of $0.20 \mathrm{~mm} / \mathrm{ka}$.

B. The upper $50 \mathrm{~cm}$ have been mixed by bioturbation resulting in constant nuclide concentrations.

C. Curve showing the effect of inheritance on both the ${ }^{10} \mathrm{Be}$ and ${ }^{21} \mathrm{Ne}$ concentrations.

Abb. 12: Entwicklung der Nuklidkonzentration $\left({ }^{10} \mathrm{Be}\right.$ und $\left.{ }^{21} \mathrm{Ne}\right)$ in Abhängigkeit von der Tiefe. Die Gesamtnuklidkonzentration ist die Summe aus ererbten Konzentrationen und der Konzentration aus der Produktion nach Ablagerung der Sequenz oder eines vormalig exponierten Tiefenprofils im Festgestein. Die ererbte Nuklidkonzentration kann durch die Beprobung in unterschiedlichen Tiefen (mehrere Proben über eine Tiefe von mindestens $2 \mathrm{~m}$ ) ermittelt werden.
A. ${ }^{10} \mathrm{Be}$ und ${ }^{21} \mathrm{Ne}$ Nuklidkonzentrationen in einem Tiefenprofil nach einer Expositionszeit von 100000 Jahren unter einer konstanten Erosionsrate von $0,20 \mathrm{~mm} / 1000$ Jahre.
B. Der obere Bereich des Profils $(50 \mathrm{~cm})$ ist durch Bioturbation homogenisiert, was zu einer konstanten Nu- klidkonzentrationen über dieses Intervall führt.
C. Darstellung des Einflusses einer ererbten Nuklidkonzentration auf die ${ }^{10} \mathrm{Be}$ und ${ }^{21} \mathrm{Ne}$ Nuklidkonzentratio- nen.


perature and precipitation patterns in a region with time (KERSCHNER 2005). Therefore if one can directly date moraines one can construct a chronological structure to past glacier fluctuations and therefore past climatic fluctuations (Kerschner \& Ivy-Ochs 2008). Depending on the detailed structure of the moraine complex the innermost moraine records the onset of glacier downwasting (Gosse 2005). For example near synchrony of glacier downwasting at the end of the Last Glacial Maximum world-wide has been established with ${ }^{10} \mathrm{Be}$ dating (SCHAEFER et al. 2006). As described above large boulders in stable positions along the moraine crest are sampled preferentially. A boulder must be large and stable enough not to have toppled or shifted and high enough to have protruded above the matrix since moraine deposition (HALlET \& Putkonen, 1994; Putkonen \& Swanson, 2003; Putkonen \& O’Neal, 2006). Key limitations include weathering of the boulder surface and degradation of the moraine itself (ZREDA et al. 1994; Zreda \& Phillips, 1995; Reuther et al. 2006a; Ivy-Ochs et al. 2007a). Sampling several small clasts on a young $(<20 \mathrm{ka})$ moraine is unlikely to give the depositional age (Ivy-Ochs et al. 2007a). Moraines ranging in age from hundreds of years to hundreds of thousands of years in both hemispheres have been dated (e.g. Phillips et al. 1990; Ivy-Ochs et al. 1999, 2006; BARrows et al. 2002; KAPLAn et al. 2004; Briner et al. 2005; BALCo \& SchaEFer 2006; Akçar et al., 2008b). The older the moraine the greater the spread in ages amongst the exposed boulders. This may make interpretation of the deposition age of moraines that are older than $100 \mathrm{ka}$ difficult (KAPLAN et al. 2005; SMITH et al. 2005). In such cases the oldest age is assumed to be closest to the landform age. But this age may still be a minimum age for the landform.

In a suite of ages from a single moraine outliers that are too old reflect inheritance. Boulders that are deposited in moraines may have acquired inheritance in the bedrock setting or because they are reworked from older moraines. For the case of a boulder suface exposed in the bedrock setting, the amount of inheritance is dependent on how long the bedrock surface was exposed (and the bedrock weathering rate) and how deep the boulder originated inside the bedrock surface (Ivy-Ochs et al. 2007a). The effect of this will be greater in younger (Holocene) moraines. Based on a compilation of numerous published moraine boulder exposure ages, Putkonen \& Swanson (2003) found that pre-exposure was observed in moraine boulders in only a few percent of cases.

\subsubsection{Glacially-modified bedrock surfaces and rates of sub-glacial erosion}

Initial deglaciation of the valley bottom and rates of glacier downwasting can be determined by analyzing cosmogenic nuclides in glacially-scoured bedrock surfaces (e.g. roche moutonnées) (Gosse et al. 1995; Guido et al. 2007). However, results from bedrock surfaces should be viewed with caution. If three meters or more of bedrock have not been removed by sub-glacial erosion during the last glaciation, then the rock surface may contain inherited nuclide concentrations. This has been noted where the rock is highly resistant (Guido et al. 2007). In the case where the timing of deglaciation is independently known (for example from exposure dating of erratics), the nuclide concentration measured in glacially-scoured bedrock can be used to determine sub-glacial erosion rates. Determined rates are on the order of 0.1 to $1 \mathrm{~mm}$ per year (BRINER \& SWANSON 1998; Colgan et al. 2002; FABel et al. 2004). Direct determination of such rates is only possible with cosmogenic nuclides.

Cosmogenic nuclides have a unique characteristic in that they can be used to elucidate fundamental information about the thermal regime of past ice sheets. Lower ${ }^{26} \mathrm{Al}$ than ${ }^{10} \mathrm{Be}$ concentrations in bedrock reveals areas where ice was frozen to its bed and unerosive (BIERMAN et al. 1999; FABEL et al. 2002; MARQUETTE et al. 2004; Staiger et al. 2005; Sugden et al. 2005; Linge et al. 2006; Phillips et al. 2006). Production ceased when the surfaces were covered by ice, ${ }^{26} \mathrm{Al}$ decays faster than ${ }^{10} \mathrm{Be}$ thus ${ }^{26} \mathrm{Al} /{ }^{10} \mathrm{Be}$ ratios plot below the erosion island (see also DEHNERT \& SCHLÜCHTER 2008). 


\subsection{Alluvial, lacustrine and marine systems}

Determining the age of alluvial landforms (for example fluvial terraces and alluvial or debrisflow fans) provides fundamental information about timing and rates of depositional processes. Constructing an age sequence also allows estimation of the contribution of the various external forcing mechanisms, such as tectonically induced base-level or regional slope changes, climatically (discharge) induced or sediment supply dependent variations. Fluvial or marine terraces; or alluvial fans can be dated using depth profiling and measuring one or more nuclides (samples from the upper 2 meters) (Perg et al. 2001; Ward et al. 2005; Ryerson et al. 2006; FranKel et al. 2007) or using burial dating (Wolkowinsky \& Granger 2004) (see also DeHNeRT \& SCHLÜChter 2008).

\subsubsection{Wave-cut bedrock platforms and paleoshorelines}

Lake and marine paleoshorelines delineate higher water levels and thus record past changes in the balance between precipitation vs. evaporation plus lake drainage and inflow or fluctuations in sea-level, respectively. In order to integrate these periods of lake/sea highstands into existing regional chronologies a time frame is required. Such highstands can be exposure dated in two ways by exposure dating wave-cut bedrock platforms or by determining the age of cobble deposits that mark ancient strandlines.

The only way to directly date a wave-cut bedrock platform is with cosmogenic nuclides. Uplifted marine wave-cut platforms in northern Spain were studied by Alvarez-Marrón et al. (2007) with ${ }^{10} \mathrm{Be},{ }^{26} \mathrm{Al}$, and ${ }^{21} \mathrm{Ne}$. Minimum ages of 1-2 Ma were calculated. Based on a comparison of ${ }^{10} \mathrm{Be}$ and ${ }^{21} \mathrm{Ne}$ data the authors suggested that the surfaces have undergone complex exposure histories and may even be Pliocene in age when the burial time is included. The data of Kong et al. (2007) from wave-cut shore lines of lake Sumxi Co, Western Tibet, agree with regional chronologies; the highest bedrock terrace was formed during enhanced discharge of melting glaciers around $12 \mathrm{ka}$. This implies that no inherited nuclides were present. Wave-cut bedrock platforms and associated boulders of the Provo shoreline which delineates the latest Pleistocene extent of Lake Bonneville have been dated with a number of cosmogenic nuclides, including ${ }^{3} \mathrm{He}$ (Cerling \& CRAIG 1994a). At that site consistent ages have been obtained with ${ }^{14} \mathrm{C}$ in quartz (LifTon et al. 2001) and ${ }^{10} \mathrm{Be}$ making it an excellent site for production rate determination and nuclide cross-calibrations. Timing of abandonment of the Provo shoreline is known from radiocarbon dating (GoDSEY et al. 2005). Cobble and pebble deposits that delineate ancient strandlines can be exposure dated either by analyzing individual clasts or by amalgamating tens of clasts together. Because of the dependency on preservation of the strandlines most of these studies are in arid regions. The primary difficulty in dating such deposits is inheritance. Inheritance is recognized when the clast exposure ages are significantly scattered and/or when they are older than the estimated age of the shoreline based on field relationships or correlations with independently dated sections. Inheritance can be acquired in the catchment when the denudation rate is low. Thus the clasts arrived in the lacustrine system with a non zero initial nuclide concentration. Clasts may have been exposed during intermittent storage in river terraces between erosion in the catchment and final deposition in the shoreline. Finally, inheritance may indicate that clasts were moved from shoreline to shoreline and thus do not give the correct age for the strandline from which they were collected. MatMON et al. (2003) dated five individual chert clasts from the ancient strandline of paleo Lake Lisan age scatter and disagreement with independent age estimates due to inheritance points to intermediate storage of clasts.

\subsubsection{Alluvial fans}

Patterns of alluvial fan deposition record variations of erosional processes in the fan catchment and changes in incision of the fan head over time (DüHNFORTH et al. 2008). When individual lobes 
can be clearly mapped then surface exposure dating is a useful tool for dating of abandoned fan lobes (DüHNFORTH et al. 2007). Original depositional forms such as flow snouts and levees are often still present on debris-flow fans that are less than $100 \mathrm{ka}$ old. To date the different fan lobes large boulders in clear position on snout or levee are sampled (BIERMAN et al. 1995; ZEHFUSS et al. 2001; DüHNFORTH et al. 2007). On older alluvial fans degradation of fan surfaces and boulder grusification leads to smoothing out of the original bar and swale morphology. After a long enough period of time (50 ka?) desert pavement of interlocking clasts develops (RYERSON et al. 2006) with associated desert varnish. In these cases amalgamated clast samples are analyzed. An important question is whether or not the dates represent the interval of lobe construction or whether they point to timing of fan abandonment. Another serious concern for the dating of alluvial and debris-flow fans is inheritance. Similar to the case of the strandline clasts inheritance can have been acquired in the catchment, in intermediate storage, or as clasts are moved from older to younger lobes. Reflecting the bedrock rezeroing effect of glaciers, inheritance is often greater in fans originating in unglaciated catchments.

\subsubsection{Fluvial incision rates}

Fluvial incision rates and their variation with time are calculated by using the exposure age and height of fluvial (WARD et al. 2005) or strath terraces (Burbank et al. 1996; Leland et al. 1998; Pratt-Sitaula et al. 2004; Reusser et al. 2004). Boulders or amalgamated clast samples on debris-flow deposits on ancient bedrock straths have been dated to determine incision rates (Fenton et al. 2004; Marchetti \& Cerling 2005). Based on ${ }^{10} \mathrm{Be}$ in samples from three strath terraces REUSSER et al. (2004) reported that incision rates of the Susquehanna River (eastern U.S.A.) more than doubled to $0.5 \mathrm{~mm} \mathrm{a}^{-1}$ during the last glaciation (32 to $16 \mathrm{ka}$ ). In Taiwan ${ }^{36} \mathrm{Cl}$ measured in samples from fluvially-sculpted limestone channel walls in Taroko Gorge indicate incision rates of $26 \mathrm{~mm} \mathrm{a}^{-1}$ (Schaller et al.
2005). Steep gorge walls may provide a more continuous record of incision than strath terraces as the latter is a step-like sequence. In any case it is often difficult to verify that strath terraces were never covered by sediment during their exposure histories. Past incision rates can also be calculated by combining burial ages of cave sediments with the height of the cave above the active river channel (GRANGER et al. 1997; STOCK et al. 2004) (see DeHNERT \& SCHLÜChtER 2008).

\subsection{Tectonic and mass movement studies}

Cosmogenic nuclides can be used to determine rates of tectonic activity in two ways i) by dating landforms that have been offset by movement along faults and ii) by dating bedrock fault surfaces directly.

\subsubsection{Dating of offset landforms}

Slip rates on strike-slip faults or rates of uplift on normal faults have been determined by taking the age and offset distances of moraines (LASSERre et al. 2002; Brown et al. 2002), fluvial terraces (Hetzel et al. 2002a) and alluvial fans (Bierman et al. 1995; SiAme et al. 1997; BROWn et al. 1998; VAN DER WOERD et al. 1998; Zehfuss et al. 2001; Ritz et al. 2003; MÉriauX et al. 2005; Ryerson et al. 2006; FranKel et al. 2007). Cautious interpretation of field evidence for offset distances (piercing point, offset terrace risers vs. treads; offset stream channels) is important (MÉRIAUX et al. 2004).

\subsubsection{Direct dating of fault surfaces}

Limestone bedrock fault surfaces are dated directly with ${ }^{36} \mathrm{Cl}$ (ZREDA \& Noller 1998; MitChell et al. 2001; BenEDETTI et al. 2002; 2003; PAlumbo et al. 2004). Suitable fault surfaces are several meters high several kilometers long, fresh, and uneroded. Samples are taken at centimeter intervals along the exposed fault surface often with a circular saw. In principle, the recurrence interval of earthquakes along the fault segment can be reconstructed based on step changes in ${ }^{36} \mathrm{Cl}$ concentrations determi- 
ned in tens of samples from a single fault face. Earthquakes that occurred as recently as only a thousand years ago are dated. In principle, such a study is also possible with ${ }^{10} \mathrm{Be}$ in quartz, but may be limited by sample preparation time for the large number of samples required. The age of the fault surface that can be determined is controlled by the karst weathering rate of the limestone and is generally restricted to those less than tens of thousands of years old.

\subsubsection{Landslides}

Landsliding is an important process for the modification of valley slopes and cross profiles, as well as overall landscape denudation especially in steep terrain. By determining the timing of recurrence intervals we can begin to understand the mechanisms of large-scale downslope movement of rock, and the interplay between various possible causes and triggers. These include inherited tectonic structures, debuttressing following retreat of glaciers, climate (precipitation, temperature, permafrost extent etc.), and/or seismic events. Several catastrophic landslides have been dated using cosmogenic nuclides: the Koefels landslide in Austria (Ivy-Ochs et al. 1998b), the Flims landslide in Switzerland (Ivy-Ochs et al. 2008), the Fernpass landslide in Austria (PRAGER et al. 2008), the Almtal landslide in Austria (vAn Husen et al. 2007); the Beinn Alligin rock avalanche, in Scotland (Ballantyne \& Stone 2004), the Blackhawk landslide in California, U.S.A. (Nichols et al. 2006), several slides in Argentina (Hermanns et al. 2001; 2004), and northern India (BARNARD et al. 2001), as well as both deep-seated and shallow landslides in Hong Kong (SEwell et al. 2006).

Although new rock surfaces are created during mass movements, exposure dating of landslides can have mixed results (Ivy-OcHs et al. 2008). Each possible sampling site (bedrock detachment zones, sliding planes, large boulders) has its own advantages and disadvantages. In the breakaway zone recent rockfall can be difficult to identify. Sliding planes with low dip angles may yield too young ages due to past coverage by snow and/or vegetation. Because of the movement mechanisms of landslides, rocks from the outer surface of the pre-slide bedrock frequently end up as boulders on top of the deposit. As a result, «too old» exposure ages with respect to independent age controls occur much more frequently in landslide boulders than in moraine boulders (Nichols et al. 2006; SEWELL et al. 2006; Ivy-Ochs et al. 2008). Never-theless exposure dating is an irreplaceable tool in landslide studies, often there is no other way to date the mass movement. Although repeated sliding may be identified during mapping, it is impossible to determine the reccurence interval without direct dating. In the Alps, post-Last Glacial Maximum landsliding in the early Lateglacial cannot be dated with radiocarbon because of a lack of organic material. Holocene landslides can be dated when entrained trees or wood fragments are discovered or by dating basal sediments of impounded lakes. Intercomparison of dating results from various methods allows better constraining of the event age.

\subsection{Volcanic sequences}

Based on detailed mapping relative eruption sequences are constructed. Lava flows can often be ${ }^{14} \mathrm{C}$ dated with entrained charcoal or by analyzing underlying burnt soil, when such material is found. Time of eruption of lava flows and domes are dated with $\mathrm{K} / \mathrm{Ar}$ and ${ }^{40} \mathrm{Ar} /{ }^{39} \mathrm{Ar}$ (Kelley 2002). Not all flows are suitable for Ar/Ar dating: i) high-K minerals may be lacking, ii) excess Ar or iii) Ar loss may be a problem. As erupted volcanic rocks are newly formed surfaces with no pre-exposure, their initial nuclide concentration is zero, they are well-suited for surface exposure dating. The most challenging aspect is to unequivocally identify the original eruptive surface to sample. This may be established by the presence of primary eruptive features such as spatter (Fig. 10), frothy glassy texture of the cooling rinds on flows or bombs, vesicles near the tops of flows, or the ropey texture of pahoehoe flows (CERling \& Craig 1994a; Fenton et al. 2001; PhilLIPS 2003). Mafic lava flows with olivine and/or 
pyroxene phenocrysts or microphenicrysts are dated with ${ }^{3} \mathrm{He}$ and/or ${ }^{21} \mathrm{Ne}$ (Kurz et al. 1990; Anthony \& Poths 1992; Cerling \& Craig 1994b; LiCCIARDI et al. 1999; 2006; FENTON et al. 2004; WiLliams et al. 2005; Duffield et al. 2006). ${ }^{21} \mathrm{Ne}$ and ${ }^{10} \mathrm{Be}$ in quartz and/or sanidine phenocrysts have been used to date ignimbrites (welded tuffs) (LibARKIN et al. 2002; KoBer et al. 2005). Volcanic rocks of intermediate composition lacking quartz or olivine or pyroxene or flows lacking phenocrysts completely can be exposure dated with ${ }^{36} \mathrm{Cl}$ (PHILLIPs 2003; ZREDA et al. 1993). This also affords the opportunity for intercomparison between the eruptive (K-Ar or ${ }^{40} \mathrm{Ar} /{ }^{39} \mathrm{Ar}$ age) and the exposure age (Fenton et al. 2001; Phillips 2003). For the dating of landforms (moraines, flood deposits, etc.) comprised of volcanic rocks ${ }^{3} \mathrm{He}$ and ${ }^{36} \mathrm{Cl}$ are well suited.

\subsection{Ancient Landscapes}

It is only since the advent of cosmogenic nuclides that rock surfaces in the arid and hyperarid deserts of southern Africa (COCKBURN et al. 1999; 2000; Fleming et al. 1999; Bierman \& CAFFEE 2001), south-central Australia (BIERman \& Turner 1995; Bierman \& CAFfee 2002; Belton et al. 2004), western South America (Nishizzumi et al. 2005; Kober et al. 2007) and Antarctica (Summerfield et al. 1999; Sugden et al. 2005) can be directly dated. The long-lived radionuclides $\left({ }^{10} \mathrm{Be}\right.$ and $\left.{ }^{26} \mathrm{Al}\right)$ and especially the noble gases $\left({ }^{3} \mathrm{He}\right.$ and $\left.{ }^{21} \mathrm{Ne}\right)$ are well suited to dating landforms that have been exposed for millions of years. Combining nuclides, for example ${ }^{10} \mathrm{Be}$ and ${ }^{26} \mathrm{Al}$ or ${ }^{10} \mathrm{Be}$ and ${ }^{21} \mathrm{Ne}$, is critical to check for continuous exposure and rule out intermittent coverage. Studies using two or more nuclides indicate that many of the ancient bedrock surfaces in the deserts have been exposed continuously, but are never-theless weathering, albeit remarkably slowly. In most cases only minimum ages can be determined. Maximum erosion rates are calculated by assuming that nuclide concentrations are in steady state. At several of these sites erosion rates range down to less than $1 \mathrm{~mm}$ $\mathrm{kyr}^{-1}$ (Cockburn \& Summerfield 2004). With cosmogenic nuclide methods, fundamental information about the age and mode of formation of ancient landscapes has been gained. High nuclide concentrations measured in Australia led to the conclusion that inselbergs are direct descendents of early Cenozoic or even Mesozoic landforms (BIERMAN \& CAFFEE 2002). Combined fission-track and low cosmogenic nuclide-derived erosion rates across the Namibian escarpment indicate that great escarpments do not form by rapid (and ongoing) escarpment retreat, but must have formed early on after continental break-up (COCKBURN et al. 2000). ${ }^{10} \mathrm{Be}$ in combination with ${ }^{26} \mathrm{Al}$ data showed that many surfaces in Antarctica have experienced single-stage, continuous exposure with remarkably low erosion rates for at least the last several million years (Nishizzumi et al. 1991; Brook et al. 1995; Ivy-Ochs et al. 1995; Summerfield et al. 1999; Matsuoka et al. 2006). The high nuclide concentrations found in rocks in the Dry Valleys Antarctica provide irrefutable support for the premise that the East Antarctic Ice Sheet has been a stable feature since its inception (SCHÄFER et al. 1999; ACKERT \& KuRz 2004). Measured pre-Pleistocene apparent exposure ages and corresponding low denudation rates characterize the deserts of northern Chile, despite active uplift (DunAI et al. 2005; Kober et al. 2007; NishiIzumi et al. 2005).

\section{Summary and outlook}

The ability to use cosmogenic nuclides to determine how long minerals have been exposed at the surface of the earth provides an unrivaled tool for determining ages of landforms and rates of geomorphic processes. Depending or rock and landform weathering rates, landforms ranging in age from a few hundred years to tens of millions of years can be dated. Because of this unique capability, the variety of applications of cosmogenic nuclides will continue to grow. Concern about methodological uncertainties, such as those associated with the production rates, the site latitude and 
altitude scaling factors, as well as the effect of past changes in the Earth's magnetic field, has led to the establishment of an international consortium made up of CRONUS-Earth (www.physics.purdue.edu/cronus) and CRONUS-EU (www.cronus-eu.net). Analysis of artificial targets and samples from natural sites with independent age control are underway to refine production rates. Scaling factors are being evaluated with neutron monitors and analysis of same age natural samples taken along altitudinal transects (for example lava flows). Numerical modeling is being used to constrain production rates and scaling factors both now and in the past. The half-lives of radioactive nuclides must be accurately known. In the case of ${ }^{10} \mathrm{Be}$, two different half-lives have been published, 1.51 and 1.34 Ma (GRANGER 2006; Nishizumi et al. 2007). When these factors are better constrained the errors of the final ages will be closer to the range of the AMS and noble gas mass spectrometry measurement uncertainties (of the order of 1-4\%). With improved knowledge of production rates and their scaling to the site, the precision of obtained ages will improve. But the accuracy of the ages remains a question of geological uncertainties. The degradation of both rock surfaces and the landforms with time imposes clear limitations on the time range and accuracy of dating. Similarly, the natural variability of samples depends on landform morphology and its age. Obtained exposure ages must be evaluated individually for conformity with field relationships, including local terrace or moraine stratigraphy and regional morphostratigraphic relationships; as well as with independent age constraints for the same or correlative features. For older landforms (more than a hundred thousand years) measurement of mulitple cosmogenic nuclides can reveal fundamental information, such as non-continuous exposure, which must be factored into interpretations (Alvarez-MARRón et al. 2007; Kober et al. 2007). Cosmogenic nuclides provide a powerful and multifaceted tool whose potential has yet to be fully realized. But this power is tempered with the need for careful sampling based on detailed field mapping.

\section{References}

ACKerT, R.P. \& KuRZ, M.D. (2004): Age and uplift rates of Sirius Group sediments in the Dominion Range, Antarctica, from surface exposure dating and geomorphology. - Global and Planetary Change, 42: 207-225.

AKÇAR, N., Ivy-Ochs, S. \& SchlǗhter, Ch. (2008a): Application of in-situ produced terrestrial cosmogenic nuclides to archaeology: A schematic review. - Quaternary Science Journal, 57/1-2: 226-238.

Akçar, N., Yavuz, V., Ivy-Ochs, S., KubiK , P.W., VArdar, M., \& Schlüchter, Ch. (2008b): A Case for a down wasting mountain glacier during the Termination-I, Verçenik Valley, NE Turkey. - Journal of Quaternary Science, 23: 273-285.

Alvarez-Marrón, J., Hetzel, R., Niedermann, S., Menéndez, R. \& Marquineez, J. (2007): Origin, structure and exposure history of a wave-cut platform more than $1 \mathrm{Ma}$ in age at the coast of northern Spain: A multiple cosmogenic nuclide approach. -Geomorphology, 93: 316-334.

Anderson, R.S., RepKa, J.L. \& Dick, G.S. (1996): Explicit treatment of inheritance in dating depositional surfaces using ${ }^{10} \mathrm{Be}$ and ${ }^{26} \mathrm{Al}$. - Geology, 24: 47-51

Anthony, E.Y. \& Poths, J. (1992): ${ }^{3} \mathrm{He}$ surface exposure dating and its implications for magma evolution in the Potrillo volcanic field, RioGrande Rift, New Mexico, USA. - Geochimica et Cosmochimica Acta, 56: 4105-4108.

Balco, G. \& Schaefer, J.M. (2006): Cosmogenicnuclide and varve chronologies for the deglaciation of southern New England. - Quaternary Geochronology, 1: 15-28.

Balco, G., Stone, J.O., Lifton, N.A. \& Dunal, T.J. (2008): A complete and easily accessible means of calculating surface exposure ages or erosion rates from ${ }^{10} \mathrm{Be}$ and ${ }^{26} \mathrm{Al}$ measurements. - Quaternary Geochronology, 3: 174-195.

Balco, G., Stone, J.O.H. \& Jennings, C. (2005): Dating Plio-Pleistocene glacial sediments using the cosmic-ray-produced radionuclides ${ }^{10} \mathrm{Be}$ and ${ }^{26}$ A. - American Journal of Science, 305: 1-41.

Ballantyne, C K. \& Stone, J.O. (2004): The Beinn Alligin rock avalanche, NW Scotland: cosmogenic ${ }^{10} \mathrm{Be}$ dating, interpretation and significance. - The Holocene, 14: 448-453.

Barnard, P.L., Owen, L.A., Sharma, M.C. \& FinKEL, R.C. (2001): Natural and human-induced landsliding in the Garhwal Himalaya of northern India. - Geomorphology, 40: 21-35. 
Barrows, T.T., Stone, J.O., Fifield, L.K. \& CressweLL, R.G. (2002): The timing of the Last Glacial Maximum in Australia. - Quaternary Science Reviews, 21: 159-173.

Belton, D.X., Brown, R.W., Kohn, B.P., Fink, D. \& FARLEY, K.A. (2004): Quantitative resolution of the debate over antiquity of the central Australian landscape: implications for the tectonic and geomorphic stability of cratonic interiors. - Earth and Planetary Science Letters, 219: 21-34.

Benedetti, L., Finkel, R., King, G., Armijo, R., Papanastassiou, D., Ryerson, F.J., Flerit, F., Farber, D. \& Stavrakakis, G. (2003): Motion on the Kaparelli fault (Greece) prior to the 1981 earthquake sequence determined from $\mathrm{Cl}-36$ cosmogenic dating. - Terra Nova, 15: 118-124.

Benedetti, L., Finkel, R., Papanastassiou, D., King, G., Armijo, R., Ryerson, F., Farber, D. \& Flerit, F. (2002): Post-glacial slip history of the Sparta fault (Greece) determined by Cl-36 cosmogenic dating: Evidence for non-periodic earthquakes. - Geophysical Research Letters, 29: 8, 1246, doi:10.1029/2001GL014510.

Bennett, C.L., Beukens, R.P., Clover, M.R., Gove, H.E., Liebert, R.B., Litherland, A.E., Purser, K.H. \& SondHEIM, W.E. (1977): Radiocarbon dating using electrostatic accelerators - Negativeions provide the key. - Science, 198: 508-510.

Bierman, P. \& CAFFEe, M. (2001): Slow rates of rock surface erosion and sediment production across the Namib Desert and Escarpment, Southern Africa. - American Journal of Science, 301: 326-358.

Bierman, P. \& Caffee, M. (2002): Cosmogenic exposure and erosion history of Australian bedrock landforms. - Geological Society of America Bulletin, 114: 787-803.

Bierman, P. \& Nichols, K.K. (2004): Rock to sediment - slope to sea with ${ }^{10} \mathrm{Be}$-rates of landscape change. - Annual Review of Earth and Planetary Sciences, 32: 215-255.

Bierman, P.R., Caffee, M.W., Davis, P.T., Marsella, K., Pavich, M., Colgan P., Mickelson, D. \& LARSEN, J. (2002): Rates and timing of earth surface processes from in-situ produced cosmogenic ${ }^{10}$ Be. - In: Grew, E.S. (ed.): Beryllium: Mineralogy, Petrology, and Geochemistry: Reviews in Mineralogy and Geochemistry, 50: 147-204.

Bierman, P.R., Gillespie, A.R. \& Caffee, M.W. (1995): Cosmogenic ages for earthquake recurrence intervals and debris flow fan deposition, Owens Valley, California. - Science, 270: 447450.
Bierman, P.R., Marsella, K.A., Patterson, C., Davis, P.T. \& CAFFEe, M. (1999): Mid-Pleistocene cosmogenic minimum-age limits for pre-Wisconsian glacial surfaces in southwestern Minnesota and southern Baffin Island: a multiple nuclide approach. - Geomorphology, 27: 25-39.

Bierman, P.R. \& Turner, J. (1995): ${ }^{10} \mathrm{Be}$ and ${ }^{26} \mathrm{Al}$ evidence for exceptionally low rates of Australian bedrock erosion and the likely existence of PrePleistocene landscapes. - Quaternary Research, 44: 378-382.

Blard, P.H., Bourlès, D., Pik, R. \& Lave, J. (2008): In situ cosmogenic ${ }^{10} \mathrm{Be}$ in olivines and pyroxenes. - Quaternary Geochronology, 3: 196-205.

Braucher, R., Benedetti, L., Bourlès, D., Brown, E.T. \& Chardon, D. (2005): Use of in situ-produced ${ }^{10} \mathrm{Be}$ in carbonate-rich environments: A first attempt. - Geochimica et Cosmochimica Acta, 69: 1473-1478.

Briner, J.P., Kaufmann, D.S., Manley, W.F., Finkel, R.C. \& CAFFEE, M.W. (2005): Cosmogenic exposure dating of late Pleistocene moraine stabilization in Alaska. - Geological Society of America Bulletin, 117: 1108-1120.

Briner, J.P. \& SWANSON, T. (1998): Using inherited cosmogenic ${ }^{36} \mathrm{Cl}$ to constrain glacial erosion rates of the Cordilleran ice sheet. - Geology, 26: 3-6.

Brook, E.J., Brown, E.T., Kurz, M.D., ACKert, R.P., Raisbeck, G. \& Yiou, F. (1995): Constraints on age, erosion, and uplift of Neogene glacial deposits in the Transantarctic Mountains determined from in situ cosmogenic ${ }^{10} \mathrm{Be}$ and ${ }^{26} \mathrm{Al}$. - Geology, 23: 1063-1066.

BRook, E.J. \& Kurz, M.D. (1993): Surface-exposure chronology using in-situ cosmogenic ${ }^{3} \mathrm{He}$ in Antarctic quartz sandstone boulders. - Quaternary Research, 39: 1-10.

Brown, E.T., Bendick, R., Bourles, D.L., Gaur, V., Molnar, P., Raisbeck, G.M. \& Yiou, F. (2002): Slip rates of the Karakorum fault, Ladakh, India, determined using cosmic ray exposure dating of debris flows and moraines. - Journal Geophysical Research, 107: 2192, doi:10.1029/ 2000JB000100.

Brown, E.T., Bourlès, D. L., Burchfiel, B.C., QIdong, D., Jun, L., Molnar, P., Raisbeck, G.M. \& Yiou, F. (1998): Estimation of slip rates in the southern Tien Shan using cosmic ray exposure dates of abandoned alluvial fans. - Geological Society of America Bulletin, 110: 377-386.

Bruno, L.A., Baur, H., Graf, T., Schlüchter, Ch., Signer, P. \& Wieler, R. (1997): Dating of Sirius Group tillites in the Antarctic Dry Valleys with 
cosmogenic ${ }^{3} \mathrm{He}$ and ${ }^{21} \mathrm{Ne}$. - - Earth and Planetary Science Letters, 147: 37-54.

Burbank, D.W., Leland, J., Fielding, E., Anderson, R.S., Brozovic, N., Reid, M.R. \& Duncan, C. (1996): Bedrock incision, rock uplift and threshold hillslopes in the northwestern Himalayas. - Nature, 379: 505-510.

Cerling, T.E. \& Craig, H. (1994a): Geomorphology and in-situ cosmogenic isotopes. - Annual Review of Earth and Planetary Sciences, 22: 273-317.

Cerling, T.E. \& Craig, H. (1994b): Cosmogenic ${ }^{3} \mathrm{He}$ production rates from $39^{\circ} \mathrm{N}$ to $46^{\circ} \mathrm{N}$ latitude, western USA and France. - Geochimica et Cosmochimica Acta, 58: 249-255.

Cerling, T.E., Poreda, R.J. \& Rathburn, S.L. (1994): Cosmogenic ${ }^{3} \mathrm{He}$ and ${ }^{21} \mathrm{Ne}$ age of the Big Lost River flood, Snake River plain, Idaho. - Geology, 22: 227-230.

Cockburn, H.A.P., Brown, R.W., Summerfield, M.A. \& SEIDL, M.A. (2000): Quantifying passive margin denudation and landscape development using a combined fission-track thermochronology and cosmogenic isotope analysis approach. - Earth and Planetary Science Letters, 179: 429-435.

Cockburn, H.A.P., Seidl, M.A. \& Summerfield, M.A. (1999): Quantifying denudation rates on inselbergs in the central Namib Desert using in situ produced cosmogenic ${ }^{10} \mathrm{Be}$ and ${ }^{26} \mathrm{Al}$. - Geology, 27: 399-402.

Cockburn, H.A.P. \& Summerfield, M.A. (2004): Geomorphological applications of cosmogenic isotope analysis. - Progress in Physical Geography, 28: 1-42.

Colgan, P. M., Bierman, P., Mickelson, D.M. \& CAFFeE, M. (2002): Variation in glacial erosion near the southern margin of the Laurentide ice sheet, south-central Wisconsin, USA; implications for cosmogenic dating of glacial terrains. - Geological Society of America Bulletin, 114: 1581-1591.

Davis, N. K., Locke, W.W., Pierce, K.L. \& Finkel, R.C. (2006): Glacial Lake Musselshell: Late Wisconsin slackwater on the Laurentide ice margin in central Montana, USA. - Geomorphology, 75: 330-345.

Davis, P.T., Bierman, P., Marsella, K.A., Caffee, M.W. \& Southon, J.R. (1999): Cosmogenic analysis of glacial terrains in the eastern $\mathrm{Ca}$ nadian Arctic; a test for inherited nuclides and the effectiveness of glacial erosion. - Annals of Glaciology, 28: 181-188.
Davis, P.T., Briner, J.P., Coulthard, R.D., Finkel, R.C. \& Miller, G.H. (2006): Preservation of Arctic landscapes overridden by cold-based ice sheets. - Quaternary Research, 65: 156-163.

Davis, R. \& Schaeffer, O.A. (1955): Chlorine-36 in Nature. - Annals of the New York Academy of Sciences, 62: 107-121.

Dehnert, A. \& Schlüchter, Сh. (2008): Sediment burial dating using terrestrial cosmogenic nuclides. - Quaternary Science Journal, 57/1-2: 208-223.

Desilets, D. \& ZREDA, M. (2001): On scaling cosmogenic nuclide production rates for altitude and latitude using cosmogenic-ray measurements. - Earth and Planetary Science Letters, 193: 213-225.

Desilets, D., Zreda, M., Almasi, P.F. \& Elmore, D. (2006a): Determination of cosmogenic ${ }^{36} \mathrm{Cl}$ in rocks by isotope dilution: innovations, validation and error propagation. - Chemical Geology, 233: 185-195.

Desilets, D., Zreda, M. \& Pradu, T. (2006b): Extended scaling factors for in situ cosmogenic nuclides: New measurements at low latitude. - Earth and Planetary Science Letters, 246: 265-276.

Duffield, W., Riggs, N., Kaufman, D., Champion, D., Fenton, C., Forman, S., McIntosh, W., Hereford, R., Plescia, J. \& Ort, M. (2006): Multiple constraints on the age of a Pleistocene lava dam across the Little Colorado River at Grand Falls, Arizona. - Geological Society of America Bulletin, 118: 421-429.

Dühnforth, M., Densmore, A.L., Ivy-Ochs, S. \& Allen, P.A. (2008): Controls on sediment evacuation from glacially modified and unmodified catchments in the eastern Sierra Nevada, California. - Earth Surface Processes and Landforms: in press.

Dühnforth, M., Densmore, A.L., Ivy-Ochs, S., Allen, P.A. \& KubiK, P.W. (2007): Timing and patterns of debris flow deposition on Shepherd and Symmes creek fans, Owens Valley, California, deduced from cosmogenic ${ }^{10} \mathrm{Be}$. - Journal of Geophysical Research-Earth Surface, 112:, F03S15, doi:10.1029/2006JF000562.

DunAI, T.J. (2000): Scaling factors for production rates of in situ produced cosmogenic nuclides: a critical re-evaluation. - Earth and Planetary Science Letters, 176: 157-169.

DUNAI, T.J. (2001): Influence of secular variation of the geomagnetic field on production rates of in situ produced cosmogenic nuclides. - Earth and 
Planetary Science Letters, 193: 197-212.

Dunai, T.J., Gonzáles Lopez, G.A. \& Juez-Larre, J. (2005): Oligocene-Miocene age of aridity in the Atacama Desert revealed by exposure dating of erosion-sensitive landforms. - Geology, 33: 321-324.

Dunne, J., Elmore, D. \& MuziKar, P. (1999): Scaling factors for the rates of production of cosmogenic nuclides for geometric shielding and attenuation at depth on sloped surfaces. - Geomorphology, 27: 3-11.

Elmore, D., Fulton, B.R., Clover, M.R., Marsden, J.R., Gove, H.E., Naylor, H., Purser, K.H., Kilius, L.R., Beukens, R.P. \& Litherland, A.E. (1979): Analysis of Cl-36 in environmental water samples using an electrostatic accelerator. - Nature, 277: 22-25.

Elmore, D., Ma, X., Miller, T., Mueller, K., Perry, M., Rickey, F., Sharma, P., Simms, P., Lipschutz, M. \& Vogt, S. (1997): Status and plans for the PRIME Lab AMS facility. - Nuclear Instruments \& Methods in Physics Research, 123: 69-72.

Fabel, D., Harbor, J., Dahms, D., James, A., Elmore, D., Horn, L., Daley, K. \& Steele, C. (2004): Spatial patterns of glacial erosion at a valley scale derived from terrestrial cosmogenic ${ }^{10} \mathrm{Be}$ and ${ }^{26} \mathrm{Al}$ concentrations in rock. - Annals of Association of American Geographers, 94: 241-255.

Fabel, D., Stroeven, A.P., Harbor, J., Kleman, J., Elmore, D. \& Fink, D. (2002): Landscape preservation under Fennoscandian ice sheets determined from in situ produced ${ }^{10} \mathrm{Be}$ and ${ }^{26} \mathrm{Al}$. - Earth and Planetary Science Letters, 201: 397 406.

FABryka-Martin, J. (1988): Production of radionuclides in the Earth and the hydrologic significance, with emphasis on chlorine-36 and iodine129. - PhD thesis. University of Arizona.

Fenton, C.R., Poreda, R.J., Nash, B.P., Webb, R H. \& Cerling, T.E. (2004): Geochemical discrimination of five Pleistocene lava-dam outburstflood deposits, western Grand Canyon, Arizona. - Journal of Geology 112: 91-110.

Fenton, C.R., Webb R.H., Pearthree, P.A., Cerling, T.E. \& Poreda, R.J. (2001): Displacement rates on the Toroweap and Hurricane faults: Implications for Quaternary downcutting in the Grand Canyon, Arizona. - Geology, 29: 1035-1038.

Finkel, R.C. \& Suter, M. (1993): AMS in the Earth Sciences. - Advances in Analytical Geochemistry, 1: 1-114.
Fleming, A., Summerfield, M.A., Stone, J.O., FiFIELD, L.K. \& Cresswell, R.G. (1999): Denudation rates for the southern Drakensberg escarpment, SE Africa, derived from in-situ-produced cosmogenic ${ }^{36} \mathrm{Cl}$ : initial results. - Journal of the Geological Society, 156: 209-212.

Frankel, K.L., Brantley, K.S., Dolan, J.F., Finkel, R.C., Klinger, R.E., Knott, J.R., Machette, M.N., Owen, L.A., Phillips, F.M., Slate, J.L. \& Wernicke, B.P. (2007): Cosmogenic ${ }^{10} \mathrm{Be}$ and ${ }^{36} \mathrm{Cl}$ geochronology of offset alluvial fans along the northern Death Valley fault zone: Implications for transient strain in the eastern California shear zone. - Journal of Geophysical Research-Solid Earth, 112: B06407, doi: 10.1029/2006JB004350.

Godsey, H.S., Currey, D.R. \& Chan, M.A. (2005): New evidence for an extended occupation of the Provo shoreline and implications for regional climate change, Pleistocene Lake Bonneville, Utah, USA. - Quaternary Research, 63: 212223.

Gosse, J.C. (2005): The contributions of cosmogenic nuclides to unraveling alpine paleo-glacier histories. - In: HuBer, U.M, BugManN, H.K.M \& Reasoner, M.A (eds.): Global Change and Mountain Regions. A State of Knowledge Overview: 39-50; Dordrecht, (Springer).

Gosse, J.C., Klein, J., Evenson, E.B., Lawn, B. \& Middleton, R. (1995): ${ }^{10} \mathrm{Be}$ Dating of the Duration and Retreat of the Last Pinedale Glacial Sequence. - Science, 268: 1329-1333.

Gosse, J.C. \& Phillips, F.M. (2001): Terrestrial in situ cosmogenic nuclides: theory and application. - Quaternary Science Reviews, 20: 14751560.

Graf, T., Kohl, C.P., Marti, K. \& Nishizumi, K. (1991): Cosmic ray produced neon in Antarctic rocks. - Geophysical Research Letters, 18: 203-206.

Granger, D.E. (2006): A review of burial dating methods using ${ }^{26} \mathrm{Al}$ and ${ }^{10} \mathrm{Be}$. - In: L.L. SiAme, L.L., Bourlès, D.L. \& Brown E.T. (eds.): In Situ-Produced Cosmogenic Nuclides and Quantification of Geological Processes, Geological Society of America Special Paper, 415: 1-16.

Granger, D. E. (2007): Cosmogenic nuclides Landscape evolution. - In: Elias, S.A. (ed.): Encyclopedia of Quaternary Sciences: 445-452; Amsterdam (Elsevier).

Granger, D.E., Kirchner, J.W. \& Finkel, R.C. (1997): Quaternary downcutting rate of the New River, Virginia, measured from differential de- 
cay of cosmogenic ${ }^{26} \mathrm{Al}$ and ${ }^{10} \mathrm{Be}$ in cave-deposited alluvium. - Geology, 25: 107-110.

Granger, D.E. \& MuziKar, P.F. (2001): Dating sediment burial with in situ-produced cosmogenic nuclides: theory, techniques, and limitations. - Earth and Planetary Science Letters, 188: 269-281.

Granger, D.E. \& Riebe, C.S. (2007): Cosmogenic nuclides in weathering and erosion. - In HoLLAND H.D.\& TuReKIan, K.K. (eds.): Treatise on Geochemistry, $2^{\text {nd }}$ ed.: 1-43; Amsterdam (Elsevier).

Granger, D.E. \& SMith, A.L. (2000): Dating buried sediments using radioactive decay and muogenic production of ${ }^{10} \mathrm{Be}$ and ${ }^{26} \mathrm{Al}$. - Nuclear Instruments \& Methods in Physics Research B, 172: 822-826.

Guido, Z.S., Ward, D.J. \& Anderson, R.S. (2007): Pacing the post-Last Glacial maximum demise of the Animas Valley glacier and the San Juan Mountain ice cap, Colorado. - Geology, 35: 739-742.

Hallet, B. \& Putkonen, J. (1994): Surface dating of dynamic landforms - young boulders on aging moraines. - Science, 265: 937-940.

Hermanns, R.L., Niedermann, S., Garcia, A.V., GoMEZ, J.S. \& Strecker, M.R. (2001): Neotectonics and catastrophic failure of mountain fronts in the southern intra-Andean Puna Plateau, Argentina. - Geology, 29: 619-622.

Hermanns, R.L., Niedermann, S., Ivy-Ochs, S. \& KUBIK, P.W. (2004): Rock avalanching into a landslide-dammed lake causing multiple dam failure in Las Conchas valley (NW Argentina) - evidence from surface exposure dating and stratigraphic analyses. - Landslides, 1: 113-122.

Hetzel, R., Niedermann, S., Ivy-Ochs, S., Kubik, P.W., TAO, M. \& GAO, B. (2002a): ${ }^{21} \mathrm{Ne}$ verus ${ }^{10} \mathrm{Be}$ and ${ }^{26} \mathrm{Al}$ exposure ages of fluvial terraces: the influence of crustal Ne in quartz. - Earth and Planetary Science Letters, 201: 575-591.

Hetzel, R., Niedermann, S., Tao, M., Kubik, P.W., Ivy-Ochs, S., Gao, B. \& Strecker, M.R. (2002b): Low slip rates and long-term preservation of geomorphic features in Central Asia. - Nature, 417: 428-432.

Ivy-Ochs, S. (1996): The dating of rock surface using in situ produced ${ }^{10} \mathrm{Be},{ }^{26} \mathrm{Al}$ and ${ }^{36} \mathrm{Cl}$, with examples from Antarctica and the Swiss Alps. - ETH PhD thesis No. 11763, Zürich.

Ivy-Ochs, S., Kerschner, H. \& Schlüchter, CH. (2007a): Cosmogenic nuclides and the dating of Lateglacial and Early Holocene glacier variations: The Alpine perspective. - Quaternary International, 164-65: 53-63.

Ivy-Ochs, S., Kober, F., Alfimov, V., KubiK, P.W. \& Synal, H.A. (2007b): Cosmogenic ${ }^{10} \mathrm{Be},{ }^{21} \mathrm{Ne}$, and ${ }^{36} \mathrm{Cl}$ in sanidine and quartz from Chilean ignimbrites. - Nuclear Instruments \& Methods in Physics Research, B259: 588-594.

Ivy-Ochs, S., Poschinger, A.v., Synal, H.A. \& MAISCH, M. (2008): Surface exposure dating of the Flims rockslide, Graubünden, Switzerland. - Geomorphology (in press).

Ivy-Ochs, S., Schlüchter, Ch., Kubik, P.W., DenTON, G.H. (1999): Moraine exposure dates imply synchronous Younger Dryas glacier advance in the European Alps and in the Southern Alps of New Zealand. - Geografiska Annaler, 81A: 313-323.

Ivy-Ochs, S., Synal, H.A., Roth, C. \& Schaller, M. (2004): Initial results from isotope dilution for $\mathrm{Cl}$ and ${ }^{36} \mathrm{Cl}$ measurements at the PSI/ETH Zurich AMS facility. - Nuclear Instruments \& Methods in Physics Research, B223-24: 623-627.

Ivy-Ochs, S., Schlüchter, Ch., KubiK, P.W., Dittrich-Hannen, B. \& Beer, J. (1995): Minimum ${ }^{10} \mathrm{Be}$ exposure ages of early Pliocene for the Table Mountain plateau and the Sirius Group at Mount Fleming, dry valleys, Antarctica. - Geology, 23: 1007-1010.

Ivy-Ochs, S., Kubik, P.W., Masarik, J., Wieler, R., Bruno, L. \& Schlüchter, Ch. (1998a): Preliminary results on the use of pyroxene for ${ }^{10} \mathrm{Be}$ surface exposure dating. - Schweizerische Mineralogisch-Petrographische Mitteilungen, 78: 375-382.

Ivy-Ochs, S., Heuberger, H., Kubik, P. W., Kerschner, H., Bonani, G., Frank, M. \& Schlüchter, CH. (1998b): The age of the Koefels event. Relative, ${ }^{14} \mathrm{C}$ and cosmogenic isotope dating of an early Holocene landslide in the Central Apls (Tyrol, Austria). - Zeitschrift für Gletscherkunde und Glazialgeologie, 134: 57-70.

Ivy-Ochs, S., Kerschner, H., Reuther, A., Maisch, M., Sailer, R., Schaefer, J., Kubik, P. W., Synal, H. A. \& SCHLÜChter, CH. (2006): The timing fof glacier advances in the northern Alpes based on surface exposure dating with cosmogenic ${ }^{10} \mathrm{Be}$, ${ }^{26} \mathrm{Al},{ }^{36} \mathrm{Cl}$ and ${ }^{21} \mathrm{Ne}$. - In: SiAme, L.L, BourLès, D.L. \& Brown, E.T. (eds.): In Situ-Produced Cosmogenic Nuclides and Quantification of Geological Processes: Geological Society of America Special Paper, 415: 43-60.

Jull, A.J., Wilson, A.E., BurR, G.S., Toolin, L.J. \& Donahue, D.J. (1992): Measurements of cosmo- 
genic ${ }^{14} \mathrm{C}$ produced by spallation in high-altitude rocks. - Radiocarbon, 34: 737-744.

Kaplan, M.R., Ackert, R.P., Singer, B.S., DougLASS, D.C. \& Kurz, M.D. (2004): Cosmogenic nuclide chronology of millennial-scale glacial advances during $\mathrm{O}$-isotope stage 2 in Patagonia. - Geological Society of America Bulletin, 116: 308-321.

Kaplan, M.R., Douglass, D.C., Singer, B.S. \& CAFFEE, M.W. (2005): Cosmogenic nuclide chronology of pre-last glacial maximum moraines at Lago Buenos Aires, 46 degrees S, Argentina. - Quaternary Research, 63: 301-315.

Kelley, S. (2002): K-Ar and Ar-Ar. - In: Porcelli, D., Ballentine, C.J., \& Wieler, R. (eds.): Noble Gases in Geochemistry and Cosmochemistry: Reviews in Mineralogy \& Geochemistry 47: 785-818.

Kelly, M.A., Ivy-Ochs, S., KubiK, P.W., von Blanckenburg, F. \& Schlüchter, Ch. (2006): Chronology of deglaciation based on ${ }^{10} \mathrm{Be}$ dates of glacial erosional features in the Grimsel Pass region, central Swiss Alps. - Boreas, 35: 634 $-643$.

Kerschner, H. (2005): Glacier-climate models as palaeoclimatic information sources: Examples from the Alpine Younger Dryas period. - In: Huber, U.M., Bugmann, H.K.M.\& Reasoner, M.A. (eds.): Global Change and Mountain Regions (A State of Knowledge Overview: 73-82; Dordrecht (Springer).

Kerschner, H. \& Ivy-Ochs, S. (2008): Palaeoclimate from glaciers: Examples from the Eastern Alps during the Alpine Lateglacial and early Holocene. - Global and Planetary Change, 60: 58-71.

Klein, J., Giegengack, R., Middleton, R., Sharma, P., Underwood, J. \& Weeks, R.A. (1986): Revealing histories of exposure using in situ produced ${ }^{26} \mathrm{Al}$ and ${ }^{10} \mathrm{Be}$ in Libyan desert glass. - Radiocarbon, 28: 547-555.

Klein, J., Middleton, R. \& Tang, H.Q. (1982): Instrumentation of an FN tandem for the detection of ${ }^{10} \mathrm{Be}$. - Nuclear Instruments \& Methods in Physics Research, 193: 601-616.

Kober, F., Ivy-Ochs, S., Leya, I., Wieler, R., Baur, H. \& MagnA, T. (2005): In situ cosmogenic ${ }^{10} \mathrm{Be}$ and ${ }^{21} \mathrm{Ne}$ in sanidine and in situ cosmogenic ${ }^{3} \mathrm{He}$ in Fe-Ti-oxide minerals. - Earth and Planetary Science Letters, 236: 404-418.

Kober, F., Ivy-Ochs, S., Schlunegger, F., Baur, H., Kubik, P.W. \& Wieler, R. (2007): Denudation rates and a topography-driven precipitation threshold in northern Chile: multiple cosmo- genic nuclide data and sediment yield budgets - Geomorphology, 83: 97-120.

Kohl, C.P. \& Nishizumi, K. (1992): Chemical isolation of quartz for measurement of in-situproduced cosmogenic nuclides. - Geochimica et Cosmochimica Acta, 56: 3583-3587.

Kong, P., NA, C. G., Fink, D., Huang, F.X. \& Ding, L. (2007): Cosmogenic ${ }^{10} \mathrm{Be}$ inferred lake-level changes in Sumxi Co Basin, Western Tibet. Journal of Asian Earth Sciences, 29: 698-703.

Kubik, P.W., Korschinek, G. \& Nolte, E. (1984): Accelerator mass-spectrometry with completely stripped ${ }^{36} \mathrm{Cl}$ Ions at the Munich postaccelerator. - Nuclear Instruments \& Methods in Physics Research, B229: 51-59.

KuRz, M.D. (1986): Cosmogenic helium in a terrestrial rock. - Nature, 320: 435-439.

Kurz, M.D., Colodner, D., Trull, T.W., Moore, R.B. \& O'Brien, K. (1990): Cosmic ray exposure dating with in-situ produced cosmogenic ${ }^{3} \mathrm{He}$ : results from young Hawaian lava flows. - Earth and Planetary Science Letters, 97: 177189.

LAL, D. (1991): Cosmic ray labeling of erosion surfaces: in-situ nuclide production rates and erosion models. - Earth and Planetary Science Letters, 104: 424-439.

Lal, D. \& Peters, B. (1967): Cosmic ray produced radioactivity on the Earth. - Handbuch der Physik: 551-612.

Lasserre, C., Gaudemer, Y., Tapponnier, P., MériauX, A.-S., Van der Woerd, J., Daoyang, Y., Ryerson, F.J., Finkel, R.C. \& CAFFeE, M.W. (2002): Fast late Pleistocene slip rate on the Leng Long Ling segment of the Haiyuan fault, Qinghai, China. - Journal of Geophysical Research, 107 2276, doi:10.1029/2000JB000060.

Leland, J., Reid, M.R., Burbank, D.W., Finkel, R. \& CAFFEE, M. (1998): Incision and differential bedrock uplift along the Indus River near Nanga Parbat, Pakistan Himalaya, from Be-10 and Al-26 exposure age dating of bedrock straths. - Earth and Planetary Science Letters, 154: 93-107.

Libarkin, J.C., Quade, J., Chase, C.G., Poths, J. \& McIntosh, W. (2002): Measurement of ancient cosmogenic ${ }^{21} \mathrm{Ne}$ in quartz from the $28 \mathrm{Ma}$ Fish Canyon Tuff, Colorado. - Chemical Geology, 186: 199-213.

Licciardi, J.M., Kurz, M.D., Clark, P.U. \& Brook E.J. (1999): Calibration of cosmogenic ${ }^{3} \mathrm{He}$ production rates from Holocene lava flows in Oregon, USA, and effects of the Earth' magnetic 
field. - Earth and Planetary Science Letters, 172: 261-271.

Licciardi, J.M., Kurz, M.D. \& Curtice, J.M. (2006): Cosmogenic ${ }^{3} \mathrm{He}$ production rates from Holocene lava flows in Iceland. - Earth and Planetary Science Letters, 246: 251-264.

Lifton, N.A., Jull, A.J.T. \& Quade, J. (2001): A new extraction technique and production rate estimate for in situ cosmogenic ${ }^{14} \mathrm{C}$ in quartz. - Geochimica et Cosmochimica Acta, 65: 19531969.

Linge, H., Brook, E.J., Nesje, A., Raisbeck, G., Yiou, F. \& Clark, H. (2006): In situ ${ }^{10} \mathrm{Be}$ exposure ages from southeastern Norway: Implications for the geometry of the Weichselian Scandinavian ice sheet. - Quaternary Science Reviews, 25: 1097-1109.

Liu, B., Phillips, F.M., Fabryka-Martin, J.T., FowlER, M.M. \& Stone, W.D. (1994): Cosmogenic ${ }^{36} \mathrm{Cl}$ accumulation in unstable landforms, 1. Effects of the thermal neutron distribution. - Water Resources Research, 30: 3115-3125.

Marchetti, D.W. \& Cerling, T.E. (2005): Cosmogenic ${ }^{3} \mathrm{He}$ exposure ages of Pleistocene debris flows and desert pavements in Capitol Reef National Park, Utah. - Geomorphology, 67: 423-435.

Marchetti D.W., Cerling, T.E. \& Lips, E.W. (2005): A glacial chronology for the Fish Creek drainage of Boulder Mountain, Utah, USA. - Quaternary Research, 64: 264-271.

Marquette, G.C., Gray, J.T., Gosse, J.C., Courchesne, F., Stockli, L., Macpherson, G. \& FINKEL, R. (2004): Felsenmeer persistence under non-erosive ice in the Torngat and Kaumajet mountains, Quebec and Labrador, as determined by soil weathering and cosmogenic nuclide exposure dating. - Canadian Journal of Earth Sciences, 41: 19-38.

Marti, K. \& Craig, H. (1987): Cosmic-ray-produced neon and helium in the summit lavas of Maui. - Nature, 325: 335-337.

Masarik, J., Frank, M., Schaefer, J.M. \& Wieler, R. (2001): Correction of in-situ cosmogenic nuclide production rates for geomagnetic field intensity variations during the past 800,000 years. - Geochimica et Cosmochimica Acta, 65: 2995-3003.

Masarik, J., Kollar, D. \& Vanya, S. (2000): Numerical simulation of in situ production of cosmogenic nuclides: Effect of irradiation geometry. - Nuclear Instruments \& Methods in Physics Research, B 172: 786-789.
Masarik, J. \& Wieler, R. (2003): Production rates of cosmogenic nuclides in boulders. - Earth and Planetary Science Letters, 216: 201-208.

Matmon, A., Crouvi, O., Enzel, Y., Bierman, P., Larsen, J., Porat, N., Amit, R. \& Caffee, M. (2003): Complex exposure histories of chert clasts in the late Pleistocene shorelines of Lake Lisan, southern Israel. - Earth Surface Processes and Landforms, 28: 493-506.

Matsuoka, N., Thomachot, C.E., Oguchi, C.T., Hatta, T., Abe, M. \& Matsuzaki, H. (2006): Quaternary bedrock erosion and landscape evolution in the Sør Rondane Mountains, East Antarctica: Reevaluating rates and processes. - Geomorphology, 81: 408-420.

Merchel, S., Braucher, R., Benedetti, L., Grauby, O. \& Bourles, D.L. (2008): Dating carbonate rocks with in-situ produced cosmogenic ${ }^{10} \mathrm{Be}$ : Why it often fails. - Quaternary Geochronology, 3: 299-307.

Mériaux, A.-S., Ryerson, F.J., Tapponnier, P., Van Der Woerd, J., Finkel, R.C., Xu, X.W., Xu, Z.Q. \& CAFFeE, M. W. (2004): Rapid slip along the central Altyn Tagh fault: Morphochronologic evidence from Cherchen He and Sulamu Tagh. - Journal of Geophysical Research-Solid Earth, 109: B06401, 10.1029/2003JB002558.

Mériaux, A.-S., Tapponnier, P., Ryerson, F.J., Xu, X.W., King, G., Van der Woerd, J., Finkel, R.C., Li, H.B., Caffee, M.W., Xu, Z.Q. \& Chen, W.B. (2005): The Aksay segment of the northern Altyn Tagh fault: Tectonic geomorphology, landscape evolution, and Holocene slip rate. - Journal of Geophysical Research-Solid Earth, 110: B04404, 10.1029/2004JB003210.

Mitchell, S.G., Matmon, A., Bierman, P.R., Enzel, Y., CAfFeE, M. \& Rizzo, D. (2001): Displacement history of a limestone normal fault scarp, northern Israel, from cosmogenic ${ }^{36} \mathrm{Cl}$. - Journal of Geophysical Research-Solid Earth, 106: 4247-4264.

Morris J.D., Gosse J.C., Brachfield, S. \& Tera, F. (2002): Cosmogenic ${ }^{10} \mathrm{Be}$ and the solid Earth: Studies in geomagnetism, subduction zone processes, and active tectonics. - In: Grew, E.S. (ed.): Beryllium: Mineralogy, Petrology, and Geochemistry, Reviews in Mineralogy and Geochemistry, 50: 207-270.

MuZIKAR, P. (2005): Geomagnetic field variations and the accumulation of in-situ cosmogenic nuclides in an eroding landform. - Geochimica et Cosmochimica Acta, 69: 4127-4131.

Nelson, D.E., Korteling, R.G. \& Stott, W.R. (1977): Carbon-14: Direct detection at natural 
concentrations. - Science, 198: 507-508.

Nichols, K.K., Bierman, P.R., Foniri, R., Gillespie, A.R., Caffee, M. \& Finkel, R.C. (2006): Dates and rates of arid region geomorphic processes. - Geological Society of America Today, 16: 4-11.

Niedermann, S. (2002): Cosmic-ray-produced noble gases in terrestrial rocks: Dating tools for surface processes. - In: PorCELli, D., BALLENTINE, C.J., \& Wieler, R. (eds.): Noble Gases in Geochemistry and Cosmochemistry, Reviews in Mineralogy \& Geochemistry, 47: 731-784.

Nishilzumi, K., Caffee, M., Finkel, R.C., Brimhall, G. \& Mote, T. (2005): Remnants of a fossil alluvial fan landscape of Miocene age in the Atacama Desert of northern Chile using cosmogenic nuclide exposure age dating. - Earth and Planetary Science Letters, 237: 499-507.

Nishizumi K., Imamura M., Caffee M.W., Southon J.R., Finkel R.C. \& McAninch J. (2007): Absolute calibration of ${ }^{10} \mathrm{Be}$ AMS standards. - Nuclear Instruments \& Methods in Physics Research B258: 403-413.

Nishizzumi K., Klein J., Middleton R. \& Craig H. (1990): Cosmogenic ${ }^{10} \mathrm{Be},{ }^{26} \mathrm{Al}$ and ${ }^{3} \mathrm{He}$ in olivine from Maui lavas. - Earth and Planetary Science Letters 98: 263-266.

Nishizzumi, K., Kohl, C.P., Arnold, J.R., Klein, J., Fink, D. \& Middleton, R. (1991): Cosmic-Ray Produced ${ }^{10} \mathrm{Be}$ and ${ }^{26} \mathrm{Al}$ in Antarctic Rocks - Exposure and Erosion History. - Earth and Planetary Science Letters, 104: 440-454.

Nishizzumi, K., Kohl, C.P., Arnold, J.R., Klein, J., Dorn, R., Fink, D., Middleton, R. \& Lal, D. (1993): Role of in situ cosmogenic nuclides ${ }^{10} \mathrm{Be}$ and ${ }^{26} \mathrm{Al}$ in the study of diverse geomorphic processes. - Earth Surface Processes, 18: 407-425.

Nishizzumi, K., Winterer, E.L., Kohl, J.R., Klein, J., Middleton, R., Lal, D. \& ARnold, J.R. (1989): Cosmic ray production rates of ${ }^{10} \mathrm{Be}$ and ${ }^{26} \mathrm{Al}$ in quartz from glacially polished rocks. - Journal of Geophysical Research, 94: 17907-17915.

Palumbo, L., Benedetti, L., Bourlès, D., Cinque, A. \& FinKel, R. (2004): Slip history of the Magnola fault (Apennines, Central Italy) from Cl-36 surface exposure dating: evidence for strong earthquakes over the Holocene. - Earth and Planetary Science Letters, 225: 163-176.

Perg, L.A., Anderson, R.S. \& Finkel, R.C. (2001): Use of a new ${ }^{10} \mathrm{Be}$ and ${ }^{26} \mathrm{Al}$ inventory method to date marine terraces, Santa Cruz, California, USA. - Geology, 29: 879-882.
Phillips, F.M. (2003): Cosmogenic Cl-36 ages of Quaternary basalt flows in the Mojave Desert, California, USA. - Geomorphology, 53: 199208.

Phillips, F.M., Ayarbe, J.P., Harrison, J. B. J. \& Elmore, D. (2003): Dating rupture events on alluvial fault scarps using cosmogenic nuclides and scarp morphology. - Earth and Planetary Science Letters, 215: 203-218.

Phillips, F.M., Leavy, B.D., JanniK, N.O., Elmore, D. \& KuBIK, P.W. (1986): The accumulation of cosmogenic chlorine-36 in rocks: A method for surface exposure dating. - Science, 231: 41-43.

Phillips, F.M., Stone, W.D. \& Fabryka-Martin, J.T. (2001): An improved approach to calculating low-energy cosmic-ray neutron fluxes near the land/atmosphere interface. - Chemical Geology, 175: 689-701.

Phillips, F.M., Zreda, M., Gosse, J.C., Klein, J., Evenson, E.B., Hall, R.D., Chadwick, O.A. \& Sharma, P. (1997): Cosmogenic ${ }^{36} \mathrm{Cl}$ and ${ }^{10} \mathrm{Be}$ ages of Quaternary glacial and fluvial deposits of the Wind River Range, Wyoming. - Geological Society of America Bulletin, 109: 1453-1463.

Phillips, F.M., Zreda, M.G., Smith, S.S., Elmore, D., Kubik, P.W. \& Sharma, P. (1990): Cosmogenic chlorine-36 chronology for glacial deposits at Bloody Canyon, eastern Sierra-Nevada. - Science, 248: 1529-1532.

Phillips, W.M., Hall, A.M., Mottram, R., Fifield, L.K. \& Sugden, D.E. (2006): Cosmogenic ${ }^{10} \mathrm{Be}$ and ${ }^{26} \mathrm{Al}$ exposure ages of tors and erratics, Cairngorm Mountains, Scotland: Timescales for the development of a classic landscape of selective linear glacial erosion. - Geomorphology, 73: 222-245.

Phillips, W.M., McDonald, E.V., Reneau, S.L. \& Pотнs, J. (1998): Dating soils and alluvium with cosmogenic ${ }^{21} \mathrm{Ne}$ depth profiles: Case studies from the Pajarito Plateau, New Mexico, USA. - Earth and Planetary Science Letters, 160: 209-223.

Pigati, J. S. \& Lifton, N.A. (2004): Geomagnetic effects on time-integrated cosmogenic nuclide production with emphasis on in situ ${ }^{14} \mathrm{C}$ and ${ }^{10} \mathrm{Be}$. - Earth and Planetary Science Letters, 226: 193-205.

Poreda, R.J. \& Cerling, T.E. (1992): Cosmogenic neon in recent lavas from the Western United States. - Geophysical Research Letters, 18: 1863-1866.

Prager, C., Ivy-Ochs, S., Ostermann, M., Synal, H.-A, \& Patzelt, G. (2008): Geology and ra- 
diometric ${ }^{14} \mathrm{C}-$-, ${ }^{36} \mathrm{Cl}$ - and Th-/U-dating of the Fernpass rockslide (Tyrol, Austria). - Geomorphology: in press.

Pratt-Sitaula, B., Burbank, D.W., Heimsath, A. \& Олна, Т. (2004): Landscape disequilibrium on 1000-10,000 year scales Marsyandi River, Nepal, central Himalaya. - Geomorphology, 58: 233-241.

Putkonen J. \& O’Neal M. (2006): Degradation of unconsolidated Quaternary landforms in the western North America. - Geomorphology, 75: 408-419.

Putkonen, J. \& Swanson, T. (2003): Accuracy of cosmogenic ages for moraines. - Quaternary Research, 59: 255-261.

Raisbeck, G.M., Yiou, F., Fruneau, M. \& Loiseaux, J.M. (1978): ${ }^{10} \mathrm{Be}$ Mass-Spectrometry with a Cyclotron. - Science, 202: 215-217.

Raisbeck, G.M., Yiou, F. \& Stephan, C. (1979): ${ }^{26} \mathrm{Al}$ Measurement with a Cyclotron. - Journal de Physique Lettres, 40: L241-L244.

RepKa, J.L., ANDERson, R.S. \& Finkel, R.C. (1997): Cosmogenic dating of fluvial terraces, Fremont River, Utah. - Earth and Planetary Science Letters, 152: 59-73.

Reusser, L.J., Bierman, P.R., Pavich, M.J., Zen, E.A., Larsen, J. \& Finkel, R. (2004): Rapid late Pleistocene incision of Atlantic passive-margin river gorges. - Science, 305: 499-502.

Reuther, A.U., Herget, J., Ivy-Ochs, S., Borodavko, P., KubiK, P.W. \& Heine, K. (2006a): Constraining the timing of the most recent cataclysmic flood event from ice-dammed lakes in the Russian Altai mountains, Siberia using cosmogenic in-situ ${ }^{10}$ Be. - Geology, 34: 913-916.

Reuther, A.U., Ivy-Ochs, S. \& HeIne, K. (2006b): Application of surface exposure dating in glacial geomorphology and the interpretation of moraine ages. - Zeitschrift für Geomorphologie, Supplement 142: 335-359.

Ritz, J.F., Bourlès, D., Brown, E.T., Carretier, S., Chery, J., Enhtuvishin, B., Galsan, P., Finkel, R.C., Hanks, T.C., Kendrick, K.J., Philip, H., Raisbeck, G., Schlupp, A., Schwartz, D.P. \& Yiou, F. (2003): Late Pleistocene to Holocene slip rates for the Gurvan Bulag thrust fault (GobiAltay, Mongolia) estimated with ${ }^{10} \mathrm{Be}$ dates. - Journal of Geophysical Research-Solid Earth, 108: B3, 2162, doi:10.1029/2001JB000553.

Ryerson, F.J., Tapponnier, P., Finkel, R.C., Mériaux, A.-S., van der Woerd, J., Lasserre, C., ChevaLIER, M.L., Xu, X.W., LI, H.B. \& King, G.C.P. (2006): Application of morphochronology to the active tectonics of Tibet. - In: Siame, L.L., Bourles, D.L. \& Brown, E.T. (eds.): In SituProduced Cosmogenic Nuclides and Quantification of Geological Processes, Geological Society of America Special Paper, 415: 61-86.

Schaefer, J.M., Denton, G.H., Barrell, D.J.A., IvyOchs, S., Kubik, P.W., Andersen, B. G., Phillips, F.M., Lowell, T.V. \& Schlüchter,CH. (2006): Near-synchronous interhemispheric termination of the last glacial maximum in mid-latitudes. - Science, 312: 1510-1513.

Schäfer, J.M., Ivy-Ochs, S., Wieler, R., Leya, I., Baur, H., Denton, G.H. \& Schlüchter, Ch. (1999): Cosmogenic noble gas studies in the oldest landscape on earth: surface exposure ages of the Dry Valleys, Antarctica. - Earth and Planetary Science Letters, 167: 215-226.

Schaller, M., Hovius, N., Willet, S.D., Ivy-Ochs, S., Synal, H.-A. \& Chen, H.-C. (2005): Fluvial bedrock incision in the active mountain belt of Taiwan from in situ-produced cosmogenic nuclides. - Earth Surface Processes and Landforms, 30: 955-971.

Schaller, M., von Blanckenburg, F., Hovius, N. \& KuBIK, P.W. (2001): Large-scale erosion rates from in situ-produced cosmogenic nuclides in European river sediments. - Earth and Planetary Science Letters, 188: 441-458.

Schaller, M., von Blanckenburg, F., Veldkamp, A., Tebbens, L.A., Hovius, N. \& Kubik, P.W. (2002): A 30000yr record of erosion rates from cosmogenic ${ }^{10} \mathrm{Be}$ in Middle Europe river terraces. - Earth and Planetary Science Letters, 204: 307-320.

Seidl, M.A., Finkel, R.C., Caffee, M.W., Hudson, G.B. \& Dietrich, W.E. (1997): Cosmogenic isotope analysis applied to river longitudinal profile evolution: Problems and interpretations. - Earth Surface Processes and Landforms, 22: 195-209. Sewell, R.J., Barrows, T.T., Campbell, S.D.G. \& FIFIELD, L.K. (2006): Exposure dating $\left({ }^{10} \mathrm{Be}\right.$, $\left.{ }^{26} \mathrm{Al}\right)$ of natural terrain landslides in Hong Kong, China. - In: Siame, L.L., Bourles, D.L. \& Brown, E.T. (eds.): In Situ-Produced Cosmogenic Nuclides and Quantification of Geological Processes, Geological Society of America Special Paper, 415: 131-146.

Siame, L.L., Bourlès, D.L., Sebrier, M., Bellier, O., Castano, J.C., Araujo, M., Perez, M., Raisbeck, G.M. \& YIoU, F. (1997): Cosmogenic dating ranging from 20 to $700 \mathrm{ka}$ of a series of alluvial fan surfaces affected by the El Tigre fault, Argentina. - Geology, 25: 975-978. 
Smith, J.A., Finkel, R.C., Farber, D.L., Rodbell, D.T. \& Seltzer, G.O. (2005): Moraine preservation and boulder erosion in the tropical Andes: interpreting old surface exposure ages in glaciated valleys. - Journal of Quaternary Science, 20: 735-758.

SRINIVASAN, B. (1976): Barites - Anomalous xenon from spallation and neutron-induced reactions. - Earth and Planetary Science Letters, 31: 129141.

Staiger, J.K.W., Gosse, J.C., Johnson, J.V., Fastook, J., Gray, J.T., Stockli, D.F., Stockli, L. \& Finkel, R. (2005): Quaternary relief generation by polythermal glacier ice. - Earth Surface Processes and Landforms, 30: 1145-1159.

Staudacher, T. \& Allègre, C. J. (1991): Cosmogenic neon in ultramafic nodules from Asia and in quartzite from Antarctica. - Earth and Planetary Science Letters, 106: 87-102.

Stock, G.M., Anderson, R.S. \& Finkel, R.C. (2004): Pace of landscape evolution in the Sierra Nevada, California, revealed by cosmogenic dating of cave sediments. - Geology, 32: 193-196.

Stone, J.O. (2000): Air pressure and cosmogenic isotope production. - Journal of Geophysical Research, 105: 23753-23759.

Stone, J.O., Allan, G.L., Fifield, L.K. \& Cresswell, R.G. (1996): Cosmogenic chlorine-36 from calcium spallation. - - Geochimica et Cosmochimica Acta, 60: 555-561.

Stone, J.O.H., Evans, J.M., Fifield, L.K., Allan, G.L. \& Cresswell, R.G. (1998): Cosmogenic chlorine-36 production in calcite by muons. - Geochimica et Cosmochimica Acta, 62: 433454.

Sugden, D.E., Balco, G., Cowdery, S.G., Stone, J.O. \& SASS, L.C. (2005): Selective glacial erosion and weathering zones in the coastal mountains of Marie Byrd Land, Antarctica. - Geomorphology, 67: 317-334.

Summerfield, M.A., Stuart, F.M., Cockbrun, H.A.P., Sudgen, D.E., Denton, G.H., Dunai, T. J. \& Marchant, D. R. (1999): Long-term rates of denudation in the Dry Valleys, Transantarctic Mountains, southern Victoria Land, Antarctica based on in-situ-produced cosmogenic ${ }^{21} \mathrm{Ne}$. - Geomorphology, 27: 113-129.

Trull, T.W., Kurz, M.D. \& Jenkins, W. J. (1991): Diffusion of cosmogenic ${ }^{3} \mathrm{He}$ in olivine and quartz: Implications for surface exposure dating. - Earth and Planetary Science Letters, 103: 241-256. van der Woerd, J., Ryerson, F.J., Tapponnier, P., Gaudemer, Y., Finkel, R., Mériaux, A.-S., Caffee, M. \& Zhao Guoguang, H. (1998): Qunlu Holocene left-slip rate determined by cosmogenic surface dating on the Xidatan segment of the Kunlun fault (Qinghai, China). - Geology, 26: 695-698.

van Husen, D., Ivy-Ochs, S. \& Alfimov, V. (2007): Mechanism and age of late glacial landslides in the Calcareous Alps; The Almtal, Upper Austria. - Austrian Journal of Earth Science, 100: 114126.

Vermeesch, P. (2007): CosmoCalc: An Excel add-in for cosmogenic nuclide calculations. - Geochemistry Geophysics Geosystems, 8: Q08003, doi:10.1029/2006GC001530.

von BlancKenburG, F. (2005): The control mechanisms of erosion and weathering at basin scale from cosmogenic nuclides in river sediment. - Earth and Planetary Science Letters, 242: 224-239.

von Blanckenburg, F., Belshaw, N.S. \& O’Nions, R.K. (1969): Separation of ${ }^{9} \mathrm{Be}$ and cosmogenic ${ }^{10} \mathrm{Be}$ from environmental materials and SIMS isotope dilution analysis. - Chemical Geology, 129: 93-99.

Ward, D.J., Spotila, J.A., Hancock, G.S. \& GalBRAITH, J.M. (2005): New constraints on the late Cenozoic incision history of the New River, Virginia. - Geomorphology, 75: 54-72.

Williams, A J., Stuart, F.M., Day, S.J. \& Phillips, W.M. (2005): Using pyroxene microphenocrysts to determine cosmogenic ${ }^{3} \mathrm{He}$ concentrations in old volcanic rocks: an example of landscape development in central Gran Canaria. - Quaternary Science Reviews, 24: 211-222.

Wolkowinsky, A.J. \& Granger, D.E. (2004): Early Pleistocene incision of the San Juan River, Utah, dated with ${ }^{26} \mathrm{Al}$ and ${ }^{10} \mathrm{Be}$. - Geology, 32: 749-752.

Yokoyama, Y., Caffee, M.W., Southon, J.R. \& NishiIzUmi, K. (2004): Measurements of in situ produced C-14 in terrestrial rocks. - Nuclear Instruments \& Methods in Physics Research, B223-224: 253-258.

Zehfuss, P. H., Bierman, P. R., Gillespie, A. R., Burke, R. M. \& CAFFEe, M. W. (2001): Slip rates on the Fish Springs Fault, Owens Valley, California, deduced from cosmogenic ${ }^{10} \mathrm{Be}$ and ${ }^{26} \mathrm{Al}$ and soil development on fan surfaces. - Geological Society of America Bulletin, 113: 241-255.

ZREDA, M. (1994): Development and calibration of the ${ }^{36} \mathrm{Cl}$ surface expsoure dating method and its 
application to the chronology of Late Quaternary glaciations. - PhD thesis. New Mexico Institute of Mining and Technology, Soccorro, USA.

ZRedA, M. \& Noller, J.S. (1998): Ages of prehistoric earthquakes revealed by cosmogenic chlorine-36 in a bedrock fault scarp at Hebgen Lake. - Science, 282: 1097-1099.

Zreda, M., Phillips, F.M., Kubik, P.W., Sharma, P. \& Elmore, D. (1993): Cosmogenic ${ }^{36} \mathrm{Cl}$ dating of a young basaltic eruption complex, Lathrop Wells, Nevada. - Geology, 21: 57-60.

ZREDA, M.G. \& PHILLIPS, F.M. (1995): Insights into alpine moraine development from cosmogenic ${ }^{36} \mathrm{Cl}$ buildup dating. - Geomorphology, 14: 149-156.

Zreda, M.G., Phillips, F.M. \& Elmore, D. (1994): Cosmogenic ${ }^{36} \mathrm{Cl}$ accumulation in unstable landforms. 2. Simulations and measurements on eroding moraines. - Water Resources Research, 30: 3127-3136. 